\title{
Huzurevlerinde Yatak Odası Mekanının Gelişim Süreci, İstanbul ve Brüksel Örneği
}

\author{
Zerrin Funda Ürük ${ }^{1 *}$, Tuğçe Öztürk ${ }^{2}$ \\ 1 İstanbul Gelişim Üniversitesi, Güzel Sanatlar Fakültesi, İç Mimarlık ve Çevre Tasarımı Bölümü, İstanbul, Türkiye (ORCID: 0000-0002-3994-5883)
} 2 İstanbul Gelişim Üniversitesi, Güzel Sanatlar Fakültesi, İç Mimarlık ve Çevre Tasarımı Bölümü, İstanbul, Türkiye (ORCID: 0000-0002-9917-1410)

(İlk Geliş Tarihi 2 Temmuz 2019 ve Kabul Tarihi 24 Temmuz 2019)

(DOI: $10.31590 /$ ejosat.593611)

ATIF/REFERENCE: Ürük, Z. F. \& Öztürk, T. (2019). Huzurevlerinde Yatak Odası Mekanının Gelişim Süreci, İstanbul ve Brüksel Örneği. Avrupa Bilim ve Teknoloji Dergisi, (16), 662-678.

\begin{abstract}
$\ddot{O} \mathbf{z}$
Bu çalışmada; yurtiçi ve yurtdışı huzurevlerinde yaşayan kişilerin mekân içi yaşam alanlarını yerinde irdelenerek, yaşlıların yoğunlukla kullandığı yatak odası mekânının, işlevsel olarak doğru ve etkin olarak kullanıma uygun olup olmadığının değerlendirilmesi amaçlanmıştır. Bu bağlamda, yaşlılık sorunları ile Türkiye'den çok daha önce karşılaşmış ve çözüm projeleri geliştirmiş $A B$ standartlarına sahip Belçika'daki huzurevlerinin mekânsal analizleri yerinde irdelenerek, elde edilen veriler sayesinde İstanbul'un gelecekte yaşlılar için daha yaşanabilir huzurevleri tasarlanmasına fayda sağlayacak öneri çalışmaları sunulmuştur. Araştırma sürecinde yaşlı bakım evi ve huzurevlerinin ulusal ve uluslararası olarak yönetmelikleri incelenmiş, yaşlıların yaşam kalitelerini yüksek düzeye ulaştırmak için yönetmeliğe uygun olarak yapılması gereken mekânsal planlamalar gözden geçirilmiştir. Buna bağlı olarak, yaşlı bakım evi ve huzurevlerinde yaşayan kişilerin yatak odası mekânının var olan yönetmeliklere bağlı olarak ve planlamadan ötürü karşılaştığı aksaklıklar irdelenecek ve huzurevi kullanıcılarının mekânsal konforunu arttıracak çözüm önerileri hakkında öneriler verilecektir. Çalışmada yurtiçi ve yurtdışı huzurevi çalışanlarından anket (yüz yüze) yolu ile veriler alınmıştır. Kurumlardan bizzat alınan ya da çizimleri yapılan mimari planlar sayesinde, yatak odası mekânlarının kapasiteleri, m2 leri ve kullanımları doğrultusunda aksaklıklar görülmüş ve öneri çalışmalar sunulmuştur. Bu çalışma sonucunda, İstanbul ve Brüksel'deki huzurevlerinde yaşayan bireylerin gereksinimlerine bağlı olarak yaşlılıkta meydana gelen değişimler dikkate alınarak, yaşam kalitelerini yüksek düzeye ulaştırmak için yatak odası mekânının planlama esnasında dikkat etmemiz gereken unsurlar tespit edilerek, yapılması gerekenler öneri çalışmaları olarak sunulmuştur.
\end{abstract}

Anahtar Kelimeler: Huzurevi tasarımı, Erişebilirlik, Ergonomi, Mimarlık, İç mimarlık

\section{Development Process of Bedroom Spaces in Nursing Homes, İstanbul and Brussels Sample}

\begin{abstract}
In this study; it is aimed to evaluate the functionally correct and effective use of the bedroom space used by the elderly by examining the living spaces of the people who living in domestic and foreign nursing homes. In this context, the spatial analysis of nursing homes in Belgium that has EU standards, which had previously encountered than Turkey the problems of old age and developed solutions, were examined on site and with the help of the obtained data, suggestions were given which would benefit the elderly in designing more livable nursing homes in Istanbul, in the future. In the research process, the national and international regulations of elderly care homes and nursing homes have been examined and spatial plans that have to be done with the regulations to bring the living quality of the elderly to a high level have been reviewed. Accordingly, the problems faced by people living in elderly care homes and nursing homes due to planning in the bedroom space will be investigated depending on the regulations and a solution proposal will be given to increase the spatial comfort of the nursing home users. In the study, data were collected via face-to-face surveys from domestic and foreign nursing home staff. Thanks to the architectural plans drawn with the data we obtained from the institutions, the defects of the bedroom spaces in terms of their capacities, $\mathrm{m} 2$ and usage were seen and suggestion works were presented. As a result of this study, the necessary things to be done during the planning of the bedroom space were presented as suggestions, taking into account the needs of the elderly
\end{abstract}

${ }^{*}$ Sorumlu Yazar: İstanbul Gelişim Üniversitesi, Güzel Sanatlar Fakültesi, İç Mimarlık ve Çevre Tasarımı Bölümü, İstanbul, Türkiye, ORCID: 00000002-3994-5883, zfuruk@gelisim.edu.tr 
and the changes in the old age in order to increase the living qualities of the individuals living in the nursing homes in Istanbul and Brussels to a high level.

Keywords: Nursing home design, Accessibility, Ergonomics, Architecture, Interior architecture

\section{Giriş}

21. Yüzyılda, tüm dünya ülkeleri açısından ön plana çıkan en önemli sorunlardan birisi yaşlanma olmuştur. Günümüzde insanların daha uzun yaşaması ve doğum oranlarının azalmasıyla beraber yaşlı nüfus oranının sayısal ve oransal olarak artmasına ve dünyamızın giderek demografik yaşlanma sürecine girmesine yol açmaktadır. Dünya Sağlık Örgütü (DSÖ)'nün yaşlanmayı kronolojik olarak ele almış ve yaptığı sınıflandırmaya göre; (URL-1)

- 0-18 yaş arası: Ergen,

- 18-65 yaş arası: Genç,

- 65-74 yaş arası: Genç-yaşl1,

- 74-84 yaş arası: Yaşlı,

- 85 yaş ve üzeri: Çok yaşlı kabul edilmektedir.

Gerekli sosyal destek sistemleri oluşturulmadan ortaya çıkan yaşlı nüfustaki patlama yılda \%3 oranında bir artışla devam etmektedir. Bugün dünya üzerindeki toplam 60 yaş ve üstü yaşlılarının nüfusunun 2015 ve 2050 yılları arasında 900 milyondan 2 milyara çıkacağ ve 2100 yıllarında ise 3,1 milyar olacağı öngörülmektedir (Şekil 1). Bu da toplam 65 yaş ve üstü nüfusun yüzde 13'lik nüfusu oluştururken 2050'de bu oranın yüzde 22'nin üzerine çıkması beklenmektedir. (URL-2)

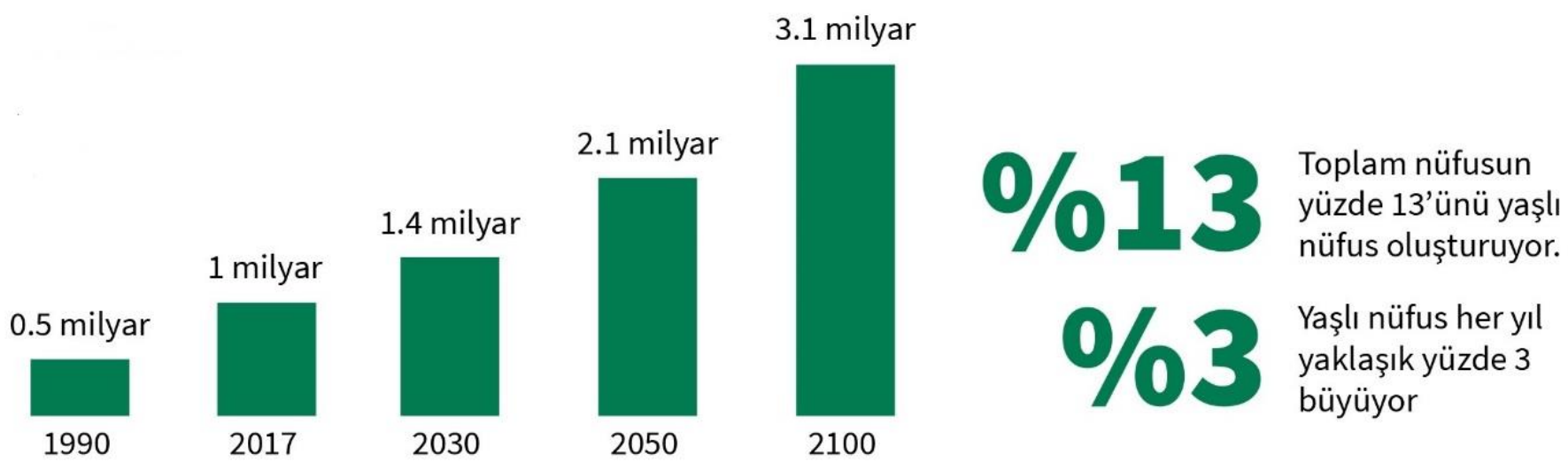

Şekil 1 Birleşmiş Milletler (BM) Dünya Nüfus Tahminleri Raporu’na göre 1990- 2100 yılları arası 60 yaş ve üzeri nüfus tahminleri (URL-3)

Dünyada en hızlı büyüyen yaşlı grubu 80 yaş üstüdür, 2000 yılında bu grubun yaşlı sayısı 70 milyondur. Bu sayının gelecek 50 yıl içinde 5 katından daha fazla artacağı beklenmektedir. Dolayısıyla, gelişmiş ülkelerin, neredeyse tümü önümüzdeki on yıllar içinde nüfuslarının yaşlanmasına tanıklık edeceklerdir (Şekil 2). Bu durum ise yaşlı nüfus için "yaşlıların yaşlanması” olarak adlandırılan bir süreci başlatacaktır. (URL-4)

Ülkemizde doğuşta beklenen yaşam süresi artmakta ve nüfusumuz yaşlanmaya devam etmektedir. Türkiye son nüfus projeksiyonlarına göre; nüfusun yaş yapısının önemli bir göstergesi olan ortanca yaşın 2018 yılında 32, 2023'te 33,5, 2040'da 38,5, 2060 'ta 42,3,2080'de ise 45 olması beklenmektedir. 65 yaş ve üzerindeki yaşlı nüfus olarak tanımlanan nüfusun ise; 2018 yılında \% $\%, 7$, 2023 'te \%10,2, 2040'da \%16,3, 2060'ta \%22,6 ve 2080'de \%25,6 oranlarında olacağı öngörülmektedir. (Şekil 3)

Yapılan araştırmalar, ülkemizin yeni bir demografik yapıya geçmekte olduğunu göstermektedir. Birleşmiş Milletler' in tanımına göre bir ülkedeki yaşlı nüfusun toplam nüfus içindeki oranının \%8 ile \%10 arasında olması o ülke nüfusunun “yaşlı”, \%10'un üzerinde olması ise "çok yaşlı" olduğu anlamına gelmektedir. Buna göre ülkemiz 2023 yılından sonra yaşlı sayısında hızla görülen artışla beraber "çok yaşlı” nüfus sıralamasının içine girecektir. (Şekil 4) 


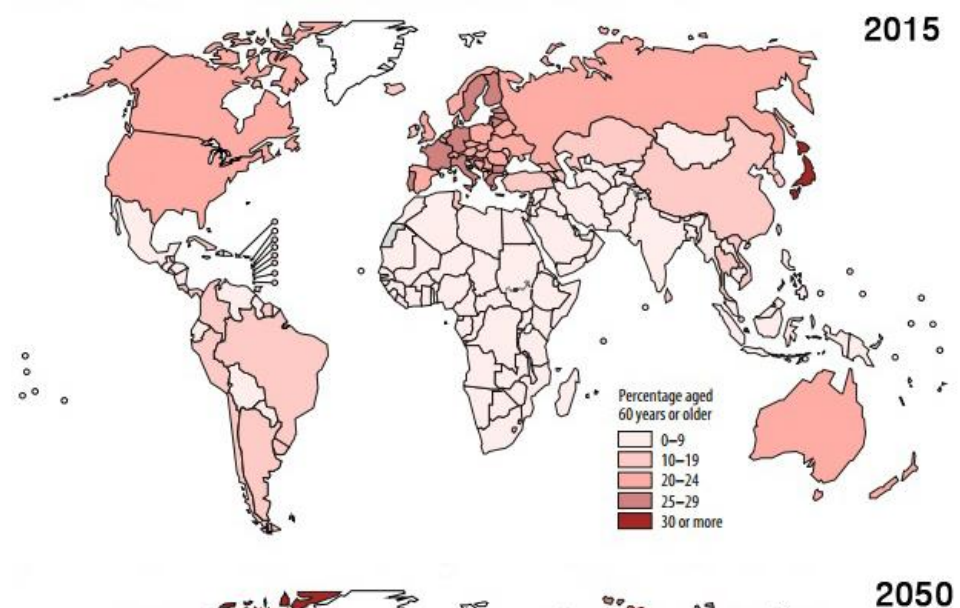

Şekil 2. Dünya 60 yaş + nüfus artışl (2015-2050) (WHO Press, 2015)

Tablo 1. Türkiye yaş yapısı değişimi (2018 -2080) (URL-5)

\begin{tabular}{llllllll} 
Yll & Toplam & $\mathbf{0 - 1 4}$ & $\mathbf{1 5 - 6 4}$ & $\mathbf{6 5}+$ & \multicolumn{3}{c}{ Oran $(\%)$} \\
\hline 2018 & 81.867 .223 & 19.203 .792 & 55.500 .077 & 7.163 .354 & 23,5 & 67,8 & 8,7 \\
2023 & 86.907 .367 & 19.601 .384 & 58.438 .033 & 8.867 .951 & 22,6 & 67,2 & 10,2 \\
2040 & 100.331 .233 & 19.333 .893 & 64.623 .369 & 16.373 .971 & 19,3 & 64,4 & 16,3 \\
2060 & 107.095 .998 & 18.126 .086 & 64.727 .126 & 24.242 .787 & 16,9 & 60,4 & 22,6 \\
2080 & 107.100 .904 & 16.813 .783 & 62.873 .761 & 27.413 .359 & 15,7 & 58,7 & 25,6 \\
\hline
\end{tabular}

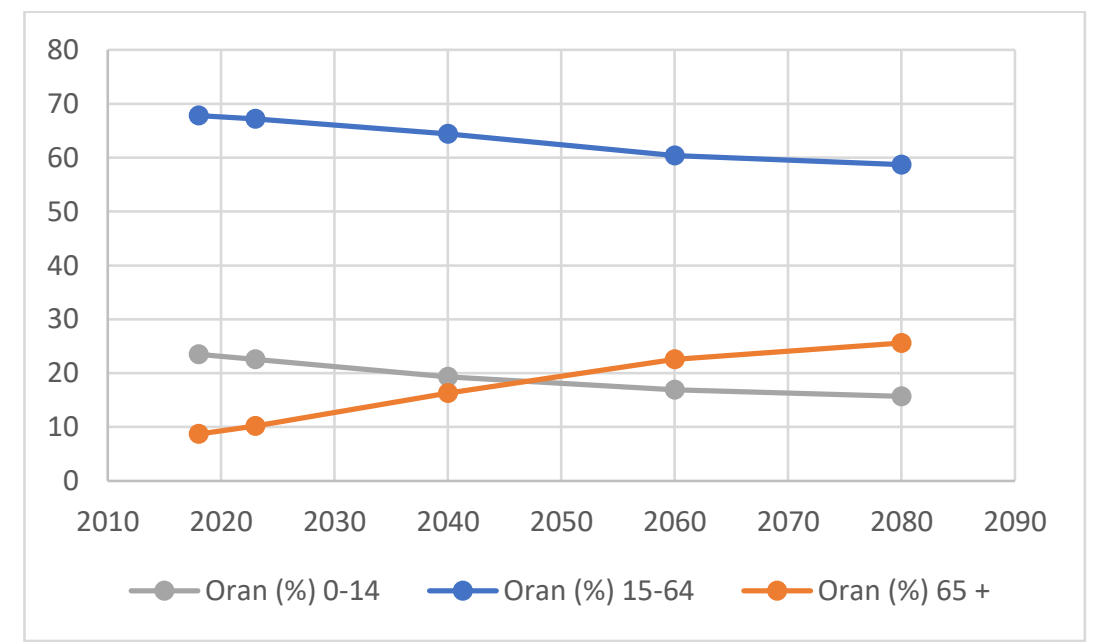

Şekil 3. Türkiye'nin 2018-2080 arast yaşlllık oranları 
TUIK'in 2018 istatistiklerine göre; Türkiye'de 2050 senesi sonrası nüfusun azaldığını ve bununla beraber yaşlı nüfusun arttı̆g gözlenmektedir. Türkiye'de 2000'li senelere kadar genç nüfus göreceli olarak daha fazla olduğundan yaşlıların sorunları hep ikinci planda kalmıştır ve bu durum bir anlamda yaşlıların sorunlarının ihmaline yol açmıştır. Ülkemizin yaşlılık sorunları da demografik yapıdaki gözlenen bu değişim sürecinde de gözlemlendiği gibi büyümeye başlamıştır. Hatta 2020’li yıllardan sonra yaşlıların oranındaki beklenen artış, yaşlıların sorunlarını en öncelikli konularından biri haline getirecektir. Demografik yapıdaki bu değişim süreci ile çok daha önce karşılaşmış ve çözüm öneri geliştirmiş olan gelişmiş ülkelerden rol-model örnekler alınması, bu hızlı değişimdeki sancıları azaltmasına katkı sağlayacaktır.

Her ne kadar Türkiye yaşlı bakımı konusunda önemli bir geçmişe sahip olsa da maalesef bu hizmetin günümüz şartlarına uygun yapıldığını söylemek güçtür. AB standartlarına sahip ülkelerin hızla terk ettiği klasik huzurevi gibi bakım konseptlerinin maalesef halen ülkemizde uygulandığı gözlenebilmektedir. Türkiye'deki huzurevlerinin yaşlının yaşam kalitesini maksimum ölçüde sürdürmek ve geliştirmek için modernize edilmesi gerekmektedir.

Hemen hemen bütün ülkelerde yaşı insanlar yaşıı bakımevlerinde kalmayı psikolojik, sosyolojik veya kültürel nedenlerden dolayı pek tercih etmemektedirler. Yapılan araştırmalar sonucu yaşlı huzurevlerinde kalan insanlar kendi ev ortamlarını ve orada geçirdikleri yaşamı ve anılarını özlemektedirler. Bunun için huzurevlerinde yaşlılara kendisini misafir gibi hissetmeyecekleri ve kendi evlerinde kalıyor duygusunu yaşatacağı mekanların tasarlamak gereklidir.

$\mathrm{Bu}$ çalışmada; huzurevlerinde yaşayan yaşlıların yaşam kalitelerini yüksek düzeye ulaştırmak için, ev ortamına en çok özdeşleştiği ve yoğunlukla kullanıldığı yatak odası mekanının planlama esnasında dikkat etmemiz gereken unsurlar tespit edilerek, yapılması gerekenler öneri çalışmaları olarak sunulmuştur. Bu bağlamda, yaşlılık sorunları ile Türkiye'den çok daha önce karşılaşmış ve çözüm projeleri geliştirmiş $\mathrm{AB}$ standartlarına sahip ülkelerden biri olan Belçika'daki huzurevlerinin mekânsal analizleri yerinde irdelenerek, elde edilen veriler sayesinde İstanbul'un gelecekte yaşlllar için daha yaşanabilir huzurevleri tasarlanmasına fayda sağlayacak öneri çalışmaları sunulmuştur.

\section{Materyal ve Yöntem}

\subsection{Huzurevi Tanımı}

Huzurevleri ile Huzurevi Yaşlı Bakım ve Rehabilitasyon Merkezleri Yönetmeliği’ne (Resmî Gazete Tarihi: 21.02.2001 Resmî Gazete Sayısı: 24325) (URL-6) göre huzurevi ve bakımevi tanımları aşağıda gibidir;

Huzurevi: +65 yaş ve üzerindeki yaşlı kişileri huzurlu bir ortamda korumak, bakmak ve bu kişilerin sosyal ve psikolojik ihtiyaçlarını karşılamak amacıyla kurulan yatılı sosyal hizmet kuruluşlarıdır.

Yaşı Bakım ve Rehabilitasyon Merkezi: Yaşlı kişilerin yaşamlarını sağlık, huzur ve güven içinde sürdürmeleri amacıyla, kendi kendilerini idare edebilecek şekilde rehabilitasyonlarının sağlandığı, tedavisi mümkün olmayanların ise sürekli olarak özel bakım altına alındığı yatılı sosyal hizmet kuruluşlarıdır.

\subsection{Huzurevi Tarihçesi}

\subsubsection{Türklerde Huzurevinin Tarihçesi ve Gelişimi}

Türklerde tarih boyunca yaşlıların toplumdaki yeri önemli olmuştur. Aile büyüklerine duyulan saygı ve onlar yaşlandığında bakımlarını üstlenmek kültürümüzün bir parçasıdır. Bu durum kültürden kültüre değişkenlik göstermektedir. İnanç ve gelenek gibi faktörler farklılıkların oluşmasında etkili olmuşlardır. Türklerde yaşlıları koruma ve yardım kurumlarının varlığının eskilere dayandığı bilinmektedir.

Yaşlıları koruma hizmetini veren ilk kurum Selçuklular döneminde 11. yüzyılda kurulmuştur. Sivas'ta 11. yüzyılda Reha Oğulları tarafından Darülreha (Huzurevi), Mısır'da Erbil Atabeyi Muzaffereddin Ebu Sait tarafından yaptırılan Gökbörü tesisleri, dört darülaceze, dullar için barınma tesisi bulunduğu saptanmıştır. Memluklular döneminde 13. yüzyılda Kahire'de açılan Seyfettin Kalavun Hastanesi ve tesisleri dul kadınlara ve yaşlılara hizmet vermiştir. (Aile ve Sosyal Politikalar Bakanlığı, 2013)

Osmanlılar döneminde imarethaneler, aşevleri ve tekkelerin varlığı ve muhtaç yaşlılara hizmet verdikleri bilinmektedir. Bu dönemde sosyal hizmetler 19. yüzyıla kadar vakıf kuruluşları tarafindan veriliyordu. 19. Yüzyılda bu alanda hizmet veren kamu kuruluşları ve hayır kurumları kurulmaya başlanmıştır. Bu kuruluşlardan bazıları 1868 yılında kurulmuş olan Kızılay Derneği ve 1895 yılında kurulmuş olan Darülacezedir. Bu kurumlar Osmanlılar döneminde kurulup günümüze kadar yaşayan kurumlardır.

Cumhuriyet'in ilanından sonra 1930 tarihinde yürürlüğü giren 1580 sayılı yasa ile ilk defa kamu kuruluşu olan Belediyelere bakıma muhtaç kişilerin (yaşlıların) korunması, yaşlı evleri yapma ve yönetme yükümlülüğü getirilmesi üzerine, değişik illerde aceze evleri, güçsüzler yurdu, düşkünler evi ve huzurevi adı altında yatılı yaşı kuruluşları açılmıştır. Aynı zamanda çeşitli dernekler, azınlıklar ve gerçek kişiler de yaşlılara hizmet vermek amacıyla yatılı yaşlı kuruluşları açmışlardır

Her türlü sosyal yardım ve güvenlik hizmetlerini düzenlemek, korunmaya muhtaç yaşlı, çocuk ve engellilerin bakımı, yerleştirilmesi ve rehabilitasyon hizmetlerini vermek üzere 1963 yllında Sosyal Hizmetler Genel Müdürlügü kurulmuştur. Bu şekilde ilk huzurevi 1966'da Konya'da, ikincisi ise Eskişehir'de açılmıştır. Daha sonrasında Bakanlar Kurulu'nca 2011 tarihinde, kamu kurumlarının yeniden yapılandırılması sürecinde Aile ve Sosyal Politikalar Bakanlığı bünyesinde Engelli ve Yaşlı Hizmetleri Genel Müdürlüğü oluşturulmuştur. 


\subsubsection{Yurtdışında Huzurevinin Tarihçesi}

Yurt dışında yaşlı bakım ve huzurevleri tarihçesinin gelişim sürecinde 1800'lerden bu yana hem insanlık hem de yaşlılar için önemli değişiklikler olduğunu görürüz. İlk dönemlerde; hiçbir imkânı ve ailesi olmayanlar yaşlılar için "işyeri (workhouses)" ve "yoksul evleri (poorhouses)" olarak adlandırılan mekânlar inşa edilmişti. Hayırseverlik amaçlı olarak inşa edilen işyeri veya fakir evleri olarak adlandırılan bu yerlerde yaşamak oldukça zordu. İçlerinde ikamet eden yaşlılar "mahkûm" olarak adlandırıldı. Cinsiyete göre ayrılmışlar, üniforma giymeye zorlanmışlar ve kaldıkları mekânın bakımını yapmak için çalışmaları gerekiyordu. Bu yerler genellikle yetimlere, engellilere, zihinsel olarak hasta insanlara ve alkoliklere ev sahipliği yapıyordu.

Yaşlıların bakım konusu zamanla geliştirildi. Zihinsel hastalar için sığınma yerleri açıldı, yoksul yaşlılar için konutlar geliştirildi. 1823'te, yaşlılar için ilk konutlardan biri olan Philadelphia'nın Indigent Widows' and Single Women's Society ABD'de açıldı. Modern bakım sisteminin temelleri 1800'lü yılların ortalarında gelişim gösterdi. Yaşlılar için devlet tarafından yürütülen kurumlara alternatif olarak çeşitli örgütler, esnaf ve dini gruplar için kâr amacı gütmeyen evler açılmaya başlandı. Bu gruplara örnek olarak Alman Yardım Cemiyeti, Odd Fellows, Masonlar ve Columbus Şövalyeleri gösterilebilir.

20. yüzyılda, yaşlanma, ilk kez, kendi başına bir çalışma alanı haline geldi. Yüzyılın ilk on yılında "gerontoloji" (yaşlanmanın incelenmesi) ve "geriatri" (yaşlanan insanlar için tıbbi bakım) terimleri ortaya çıktı. Bugün, yaşlı nüfus hızla artmaktadır ve yaşlanan nüfustaki bu artış sebebiyle klasik kurumsal huzurevlerine alternatif olabilecek kurumlara olan gereksinim de çoğalmıştır. (URL-7)

\section{Araştırma Sonuçları ve Tartışma}

\subsection{Standartlara Göre Huzurevlerinin Yatak Odası Mekanları}

\subsubsection{Türkiye Standartlart}

Huzurevleri ile Huzurevi Yaşlı Bakım ve Rehabilitasyon Merkezleri Yönetmeliği’ne göre; her kuruluşun arsa ve bina koşulları ile olanaklarına uygun olarak; dış mekândan iç mekâna doğru huzurevleri mekânlarında olması gereken mahaller belli edilmiş ve yatak odası mekânının standartları şu şekilde ifade edilmiştir;

Yaşı odaları; ev ortamına uygun olarak döşenir ve kalacak yaşlı sayısı kadar karyola, yatak, etajer, gardırop, sandalye ve koltuk bulundurulur. Her odada bir masa olması esastır. Odalardaki mobilyaların ahşap malzeme olması tercih edilir. Odalarda yaşlının yatarken uzanabileceği yükseklikte alarm düzeneği kurulur. Tüm oda donanımının sık silinmeye uygun malzemeden olmasına dikkat edilir. Zeminin halı ile kaplanması yerine parça halı kullanılması tercih edilir. Olanaklar ölçüsünde zemin anti-statik, anti-bakteriyel malzeme ile döşenir. Oda ve banyo kapılarının tekerlekli sandalye ve yürüteçlerin rahat hareket edebileceği genişlikte olmasına özen gösterilir. Banyo ve tuvalet mekânı mümkün mertebe yatak odası içerisinde çözümlenmesi istenir. Lavaboların yaşlı ergonomisine uygun yükseklikte olması sağlanır. Ayna, etajer, sabunluk ve havluluk sabitlenir. Banyo musluklarının önüne sabitlenecek oturakların hijyenik malzemeden olması tercih edilir. Sifonların yaşlıların kolay kullanabileceği teknikte olması tercih edilir. (URL-8)

\subsubsection{Avrupa ve Belçika Standartları}

Avrupa Standardizasyon Komitesi’ne göre Avrupa nüfusu yaşlanıyor ve yaşlanmaya bağlı engellilik de dahil olmak üzere yaşlı nüfusun Avrupa çapında yaygınlığı artıyor. Yaşlı insanların ve engellilerin, yaklaşık 80 milyon kişiye, yani Avrupa Birliği nüfusunun büyük ve artan bir yüzdesine sahip olduğu tahmin ediliyor.

Avrupa Birliği ülkelerinden biri olan Belçika'nın Avrupa Huzurevleri ve Yaşlı Bakım Standartları ile uyum gösterdiği, bununla birlikte yerel şartlara dayanan belli birtakım değişimlerde gösterdiği görülmektedir. Belçika Huzurevleri Çerçeve Yönetmeliğine (2006) göre; Mekânların altyapısı ve ekipman/donanımlarına ilişkin minimum standartlar belirtilmiştir ve buna göre yatak odası mekânına ait standartlar aşağıda belirtilmektedir.

Yatak Odaları; odalar kişilerin rahatça kullanabilecekleri genişlikte olup maksimum konforla donatılmalıdır. Odalarda izin verilen maksimum yatak sayısı 2 adettir. Yaşlılar isterlerse bireysel odalarda kalabilirler. Tek kişilik oda yüzey alanı $8 \mathrm{~m} 2$ 'den küçük, çift kişilik oda yüzey alanı $12 \mathrm{~m} 2$ 'den küçük olamaz. Çift kişilik odalarda yeterli mahremiyet sağlanmalıdır. Odalar normatif olarak belirlenmiş yüzey alanına uygun olmalı ancak bakıma muhtaç sakinler için gerekli materyallerin kullanılabileceği uygun genişlik sağlanmalıdır. Odalarda gömme dolap, masa ve sandalyeler, koltuk ve TV ünitesi bulunmalıdır. Yatak başlarında ve banyo mekânlarında gerekli yerlerde alarm düzeneği olmalıdır. Yeni inşa edilecek binalarda tercihen daha fazla konfor ve daha fazla alan sağlanması opsiyon dâhilindedir. Oda mekânları ve donanımları tekerlekli sandalye kullanıcıları için gerekli olan donatılar ile yeterli şekilde donatılmalıdır. İç mekânda kullanılan zemin malzemesi hijyenik olması esastır. Odalarda yaşlılara uygun tuvalet, duş teknesi ve ekipmanlarını içeren ıslak hacim mekânı bulunmalıdır. Banyolar, tekerlekli sandalye kullanıcılarına uygun donatılmış olmalıdır. Banyo içerisinde sıcak ve soğuk su sağlayan lavabolar bulunmalıdır. Tuvalet ve banyo mekânlarında havalandırma sistemi olmalıdır. (URL-9)

\subsection{Huzurevlerinde Yatak Odası Mekanları ve Mekân Standartları}

Yaşlılara yönelik hizmet veren, huzurevleri, yaşlı apartmanları, yaşlı hastaneleri, bakım evleri gibi yaşlı barınma mekânları dediğimiz kurumlarda son on yılda mekânsal kalite ve kişisel yaşam alanlarını oluşturma özgürlüğ̈ konuları gündeme gelmiş ve bu konularda önemli gelişmeler olmuştur. Bu kurumlarda yaşayan yaşlılar için ev rahatlı̆̆ı ve ortamının oluşturulması konusunun yaşlılar üzerindeki fiziksel ve psikolojik olumlu etkileri kanıtlanmıştır. 1970-80 döneminde oldukça küçük ve konforsuz mekânlar tasarlanırken, 1990'ların sonunda yaşlıların eleştirileri dikkate alınarak mekânsal kalite açısından daha iyi mekânlar sunulmaya başlanmıştır. 
Her ne kadar Türkiye yaşlı bakımı konusunda önemli bir geçmişe sahip olsa da maalesef bu hizmetin günümüz şartlarına ve $A B$ standartlarına uygun yapıldığını söylemek güçtür. $\mathrm{AB}$ standartlarına sahip ülkelerin hızla terk ettiği klasik huzurevi gibi bakım konseptlerinin de maalesef halen ülkemizde uygulandığı gözlenebilmektedir.

Yapılan araştırmalar sonucu huzurevlerinde kalan yaşlıların kendi ev ortamlarını ve orada geçirdikleri yaşamı ve anılarını özledikleri görülmüştür. Bunun için huzurevleri tasarımları yapılırken yaşlılara kendisini misafir gibi hissetmeyecekleri ve kendi evlerinde kalıyor duygusunu yaşatacağı mekânların tasarlanmasına dikkat edilmesi gereklidir.

Bu çalışmada; huzurevlerinde yaşayan yaşlıların yaşam kalitelerini yüksek düzeye ulaştırmak için, ev ortamına en çok özdeşleştiği ve yoğunlukla kullanıldığı yatak odası mekânının planlama esnasında dikkat etmemiz gereken unsurlar tespit edilerek, yapılması gerekenler öneri çalışmaları sunulmuştur. Bu bağlamda, yaşlılık sorunları ile Türkiye'den çok daha önce karşıllaşmış ve çözüm projeleri geliştirmiş $\mathrm{AB}$ standartlarına sahip ülkelerden biri olan Belçika'nın Brüksel kentindeki huzurevleri ile İstanbul'daki huzurevleri karşlıklı olarak incelenmiştir.

Brüksel ve İstanbul örneği incelemeye alınmasında; her iki kentinde metropol özellikte olması, bulundukları ülkenin ekonomik faaliyetlerinin bu kentlerde gerçekleşiyor olması, yaşlı nüfus oranının ülke ortalamasının üstünde olması ve giderek artacağının öngörülmesi gibi etkenleri sıralayabiliriz.

Belçika (Brüksel) ve Türkiye (İstanbul), huzurevleri ve yaşlı bakım merkezleri standartları kapsamında yapılmış olan incelemeler sonucu seçilen belli başlı huzurevlerine ait olan yatak odası mekânlarının analizleri yerinde irdelenerek, elde edilen veriler sayesinde İstanbul'un gelecekte yaşlılar için daha yaşanabilir huzurevleri tasarlanmasına fayda sağlayacak öneri çalışmaları sunulmuştur. Yurtiçi ve yurtdışı seçilen huzurevlerinden tek kişilik, çift kişilik veya üç kişilik örnek yatak odası mekânları seçilmiş ve bu mekânlar yerinde ölçümler ve tespitler yapılarak teknik çizimlere yansıtılmıştır. Bu çizimler üzerinden daha önce bahsettiğimiz standartlara göre uygunluk incelemesi yapılmıştır. Seçilen İstanbul örnekleri ve Brüksel örnekleri ayrı olarak sunulmuştur. Bu kapsamda hem mekânların ait oldukları ülke standartlarına olan uygunluğu hem de seçilen iki ayrı şehrin birbiriyle olan kıyaslaması yapılmıştır.

\subsection{1. İstanbul Örnekleri}

Çalışma kapsamında İstanbul bölgesinden 3 ayrı huzurevi seçilmiştir. Kullanılan huzurevleri 1, 2 ve 3 şeklinde numaralandırılmıştır. Seçilen huzurevleri birebir incelenmiş yapılan ölçümler ve tespitler sonucunda yatak odası mekânlarının planlama şemaları çıarıllmıştır. Mekânlara ait planlar aşă̆ıda sunulmuştur.

Şekil 4'de gösterilen 1 Numaralı Huzurevi'ne ait tek kişilik yatak odası planı 13,28 m2 yatma alanı ve 2,72 m2 1slak hacim alanı olmak üzere toplam $16 \mathrm{~m} 2$ alandan oluşmaktadır. Oda bir kişilik kullanıcı profiline göre düzenlenmiştir. Temel ihtiyaçlar olan yatak, giysi dolabı, buzdolabı, masa ve sandalyeler odada mevcuttur. Bunun yanı sıra sslak hacimde olası engelli kullanıma uygun düzenleme görülmemektedir. Oda içi tekerlekli sandalye dolaşımına ilişkin olarak ise herhangi bir engel olmadığı görülmektedir. Cephedeki geniş pencerelerin önünde herhangi bir güneş kırıcı eleman olmadı̆̆ından dolayı, gün ışığı mekâna gerektiğinden fazla girmesine neden olmaktadır. Kontrolsüz gün ışığının insan sağlığı ve psikolojisi üzerinde olumsuz sonuçları olmaktadır, bu tip kurumlarda dikkat edilmesi gereken önemli konulardan biridir.

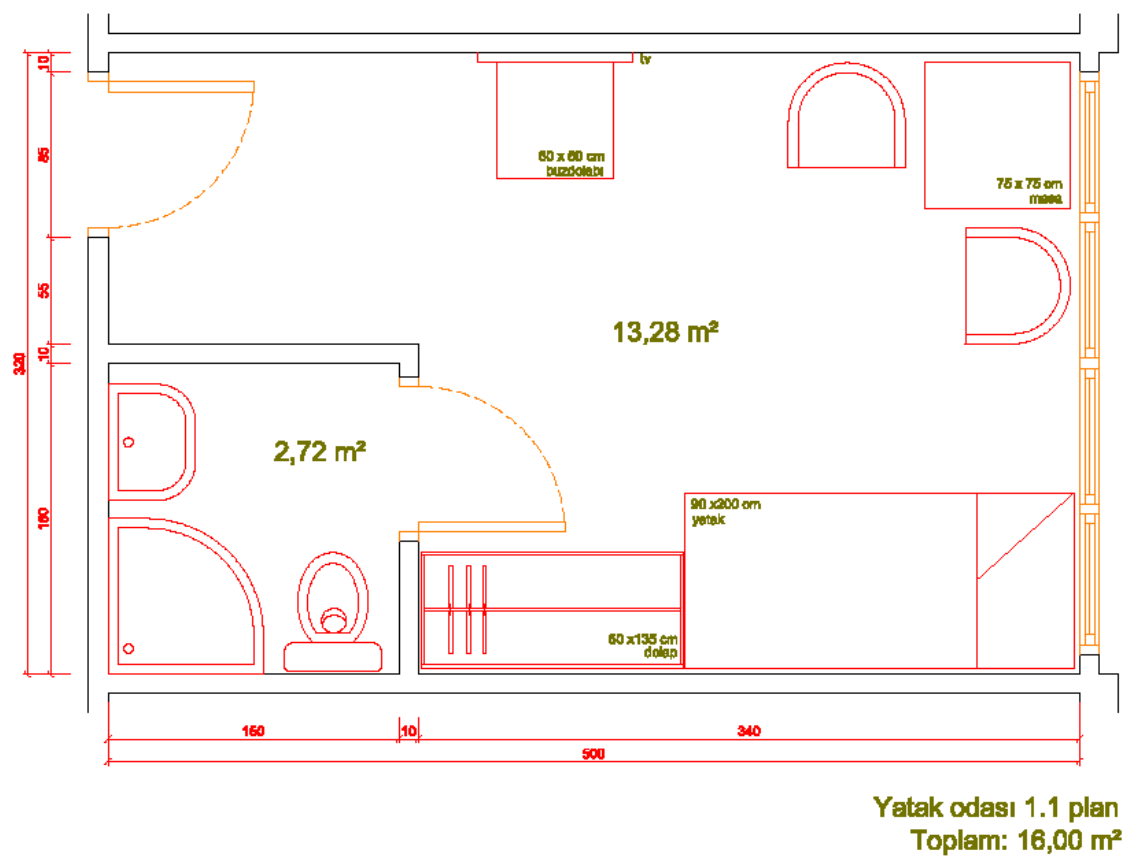

Şekil 4. 1 Numaralı Huzurevi Tek Kişilik Yatak Odası Planı (Kaynak: Yazarın Kişisel Arşivinden)

Şekil 5'de gösterilen 1 Numaralı Huzurevi'ne ait çift kişilik yatak odası planı 16,20 m2 alandan oluşmaktadır. Odada iki kişinin kullanımına uygun olacak şekilde 2 yatak, 2 giysi dolabı, buzdolabı, masa ve sandalyeler mevcuttur. Odada 1slak hacim mekânının 
bulunmaması olası engelli kullanıcıların ihtiyaçlarını karşılamalarının zorlaşmasına sebep olabilecektir. Cephedeki geniş pencerelerin önünde herhangi bir güneş kırıcı eleman olmadığından dolayı, gün ışı̆̆ı mekâna gerektiğinden fazla girmesine neden olmaktadır.

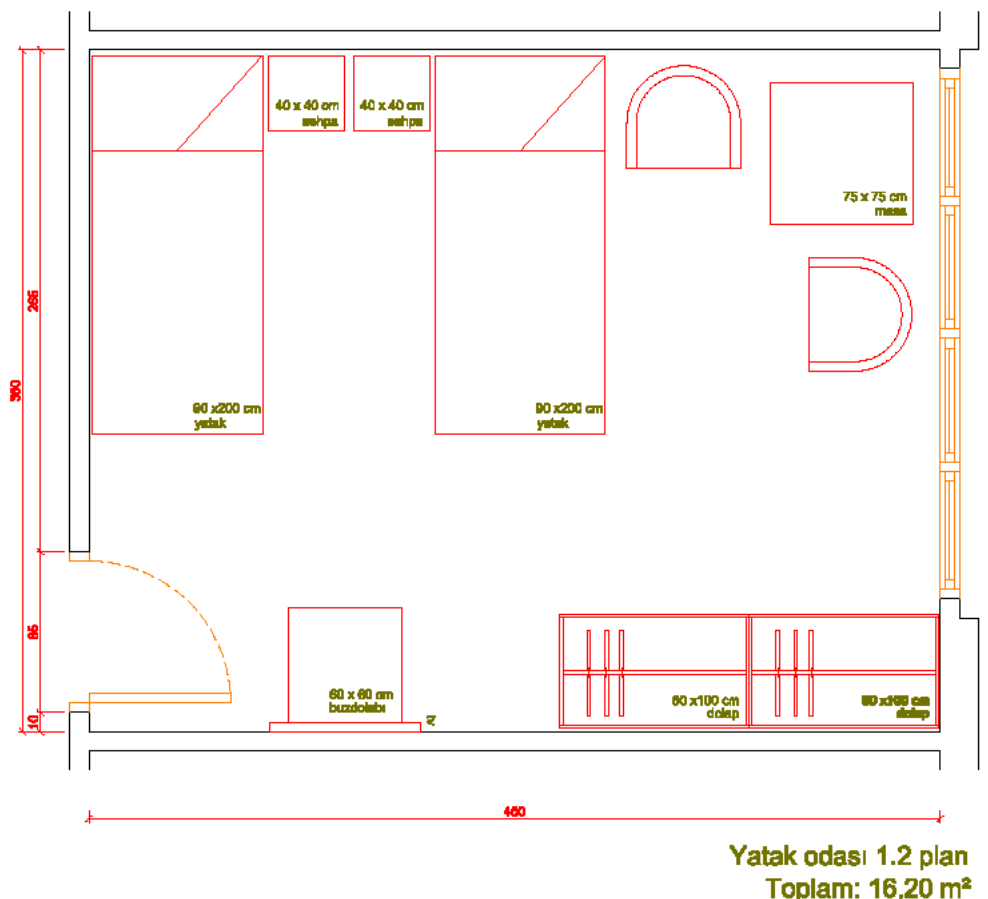

Şekil 5. 1 Numaralı Huzurevi Çift Kişilik Yatak Odası Planı (Kaynak: Yazarın Kişisel Arşivinden)

Şekil 6'da 1 Numaralı Huzurevi'ne ait tek kişilik oda planı gösterilmektedir. Buna göre olası engellinin veya yaşlının kullanacağı yatak son derece yanlış konumlandırılmıştır. Yatağı kullanan kişinin yattığı esnada pencereyi açması ve odayı havalandırması mümkün görünmemektedir. Açık olan pencere yatan kişi için tehlike arz etmektedir. Ayrıca yatağın radyatörün hemen yanında olması da kışın ısıtma sisteminin açılmasıyla birlikte yatan kişiyi rahatsız edecektir. Bunlara ek olarak, yatak yaşlı ve engelli kullanımına uygun değildir. Öyle ki, yaşlı ve engelli kullanımına uygun ortopedik ve hareket ettirilebilir yataklar mevcuttur ve böyle kurumlarda bu tip yataklar kullanılmalıdır. Yatağın yanında yaşlı kişinin olası durumlara karşı kullanabileceği bir acil çağrı butonu bulunmamaktadır. Bu tip kurumlarda acil çağrı butonunun yatağın yanında, kullanıcının ulaşabileceği bir noktada bulundurulması hayati önem taşımaktadır. Oda içerisinde kullanılan mobilyalar sivri köşelere sahiptir. Bu tehlikeli bir ortam oluşmasına sebep olmaktadır. Bunun yerine oval köşelere sahip mobilyalar kullanıcı açısından daha güvenli olacaktır. Odada kullanılan renkler ve desenler ise karmaşı, uyumsuz ve göz yorucudur. Odaların mümkün olduğunca sade olması ve dekorasyon ile ilgili bazı tercihlerin kullanıcıya bırakılması, kullanıcının ev ortamı ve rahatlığında desteklenmesi ve yaşayacağı mekânı benimsemesi açısından önemlidir. Seçilen renklerin ise dinlendirici renkler olarak adlandırdığımız pastel renklerden seçilmesi ve açık, aydınlık tonlarda olması tercih edilmelidir. Örnekte karmaşık desene sahip bir duvar kâğıdı, uyumsuz renkler, birbirinden çok farklı formlara sahip mobilya ve elemanların tercih edildiği görülmektedir. Bu da oda içinde karmaşaya yol açmaktadır. Ayrıca odanın yeteri kadar ışık almadığı ve karanlık olduğu görülmektedir. Diğer taraftan ise, yer döşemesi yumuşak ve kaymaz özellikte olmasından dolayı doğru tercih edilmiştir.

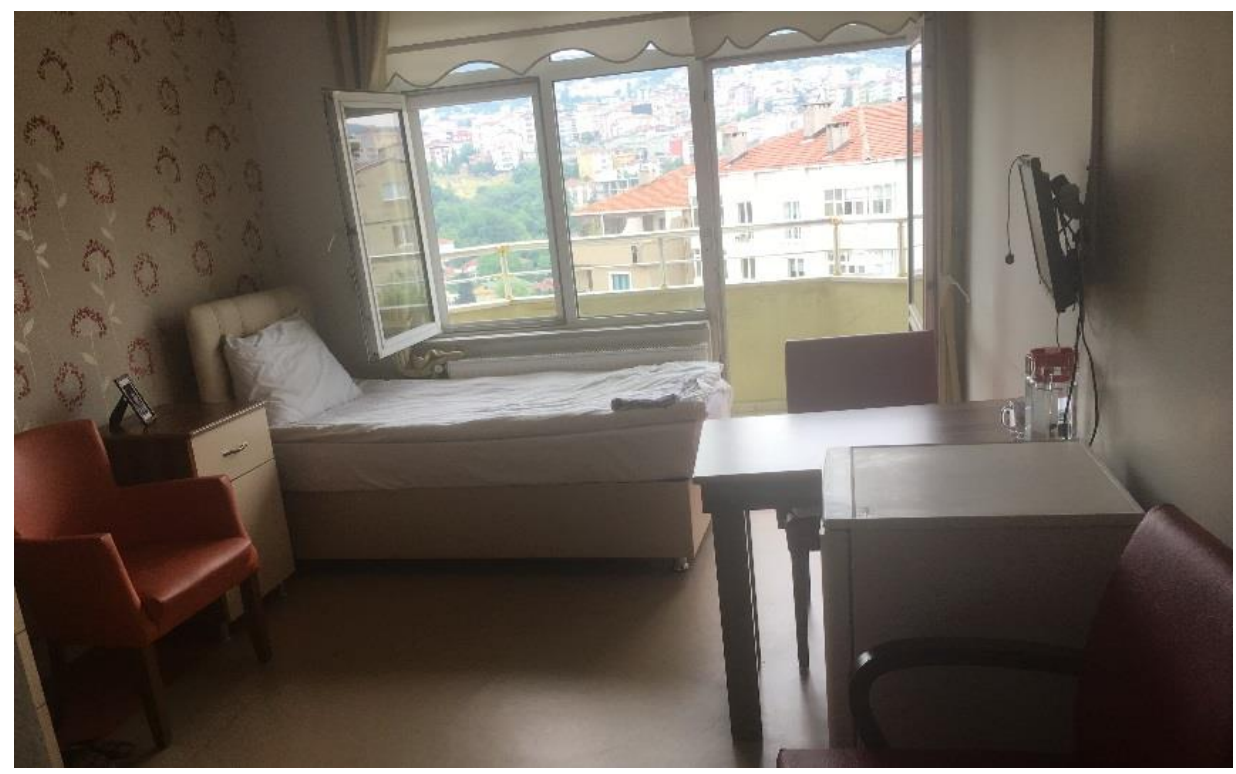

Şekil 6. 1 Numaralı Huzurevi Tek Kişilik Oda (Kaynak: Yazarın Kişisel Arşivinden) 
Şekil 7'de 1 Numaralı Huzurevi'ne ıslak hacim ve tuvalet gösterilmektedir. Tuvaletin yanında kullanılan engelli kullanıcılara yönelik tutunma barı tek başına yetersizdir. Engelli kullanıcılara yönelik daha fazla eleman ve tutunma barı bulunmalıdır. Yer döşemesinde kullanılan seramik karolar kaygan özelliktedir ve tehlike arz etmektedir. Diğer taraftan, 1slak hacimde acil çağrı butonu olduğu görülmektedir.

Şekil 8'te 1 Numaralı Huzurevi’ne kapı eşiği görseli gösterilmektedir. İki ayrı mekân arasında geçiş sağlayan kapı eşiğinin hem zemin olması gerekmektedir. Resimde görülen eşikteki çıkıntı olası engelli kullanımı açısından uygun değildir. Ayrıca bu çıkıntı kir birikimine yol açtığından dolayı hijyenik olmayan bir ortam ve görüntü oluşturmaktadır. Zeminde kullanılan seramik karoların da kaygan özelliğinden dolayı uygun olmadığı görülmektedir.
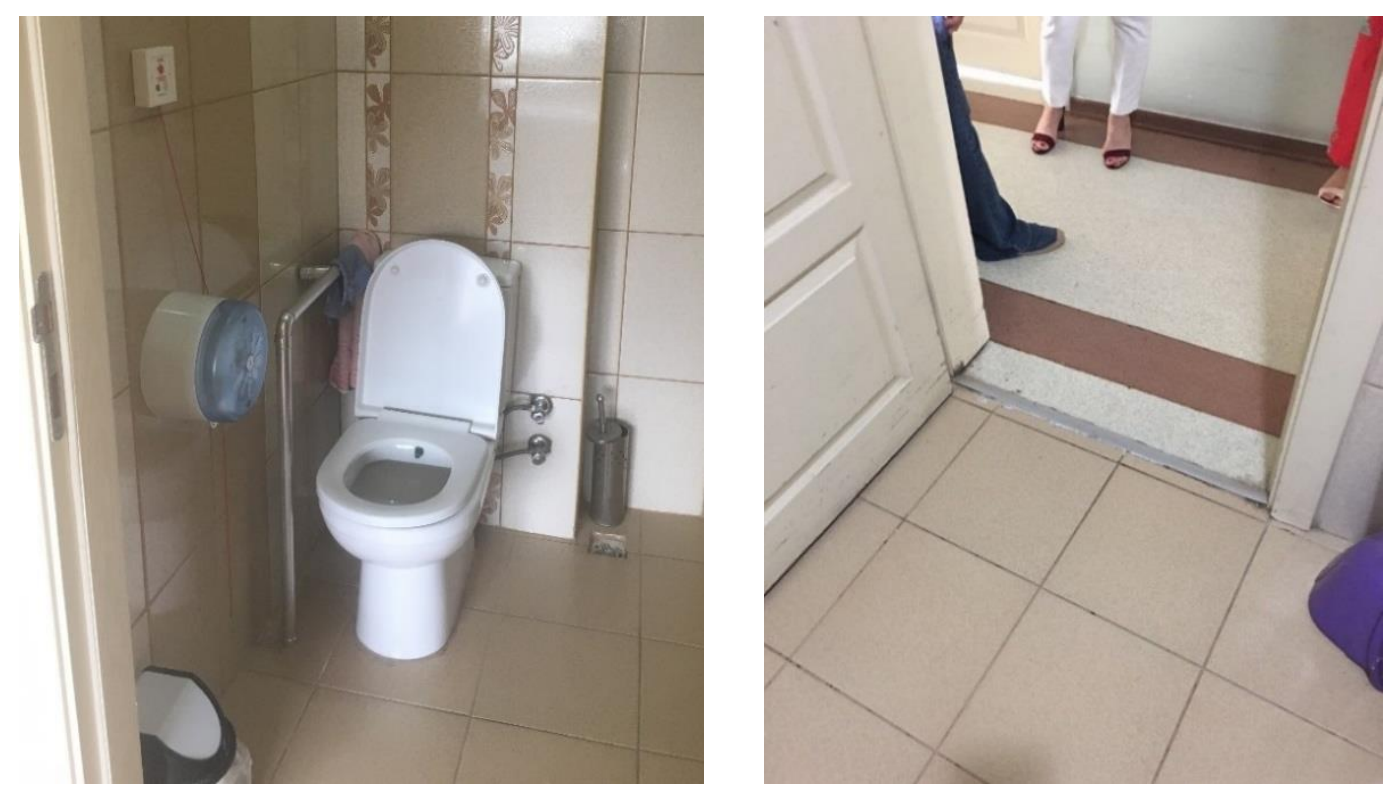

Şekil 7-8. 1 Numaralı Huzurevi Islak Hacim Mekânı Tuvalet ve Kapı Eşiği Görseli (Kaynak: Yazarın Kişisel Arşivinden)

Şekil 9'te gösterilen 2 Numaralı Huzurevi'ne ait çift kişilik yatak odası planı 20,22 m2 yatma alanı, 2,73 m2 1slak hacim alanından oluşmaktadır. Oda iki kişilik kullanıma uygun olacak şekilde 2 yatak, 2 giysi dolabı, buzdolabı, televizyon ve ünitesi, masa ve sandalyelerden oluşmaktadır. Odanın engelli kullanıcı dolaşımına uygun olduğu görülürken ıslak hacimde bu kullanıcılara yönelik herhangi bir uygulama olmadığı görülmektedir. Oda gün ışığından yararlanma hususunda uygun açıklıklara sahiptir.

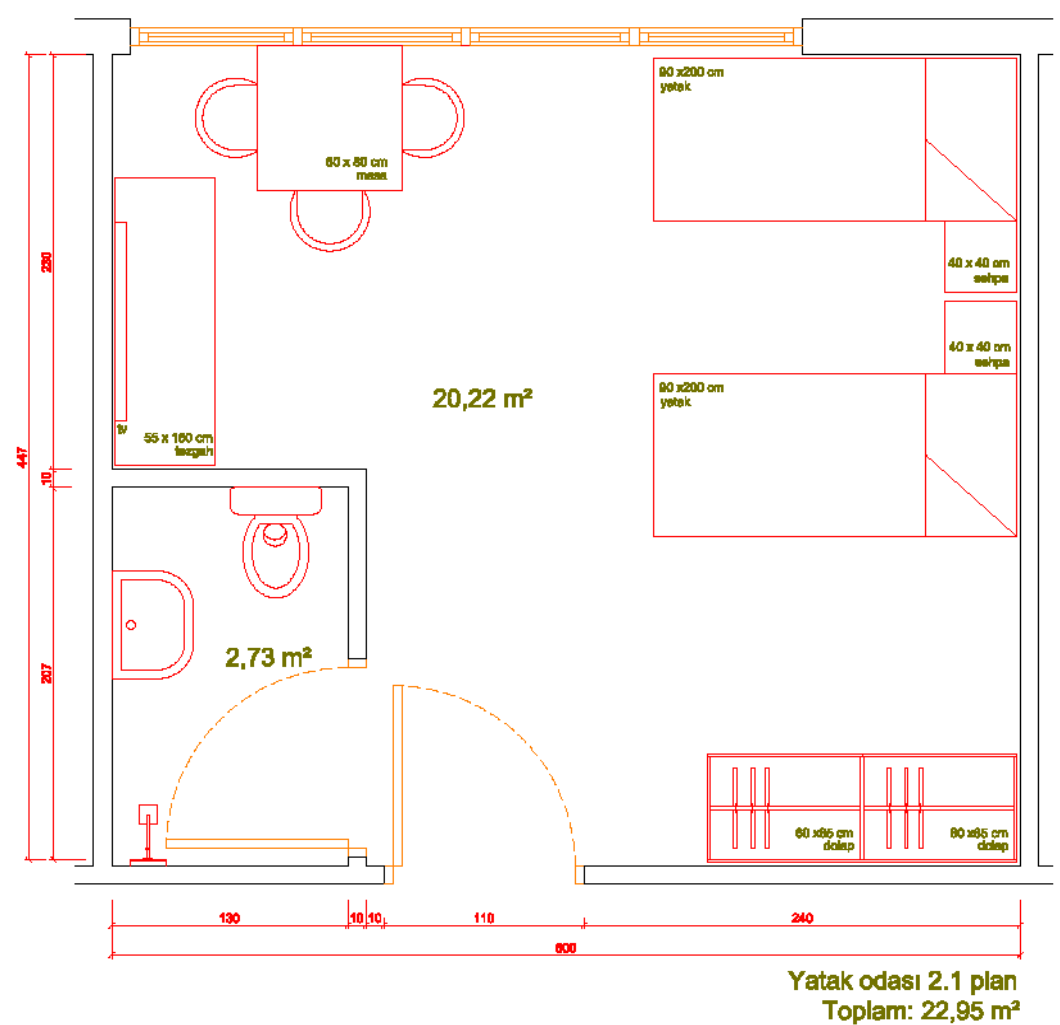

Şekil 9. 2 Numaralı Huzurevi Çift Kişilik Yatak Odası Planı (Kaynak: Yazarın Kişisel Arşivinden) 
Şekil 10'da 2 Numaralı Huzurevi'ne ait tek kişilik yatak odası planı gösterilmiştir. Oda 14,90 m2 yatma ve yaşam alanı, 3,10 m2 banyo ve wc alanı olmak üzere toplam $18 \mathrm{~m} 2$ alandan oluşmaktadır. Oda tek kişilik kullanıma uygundur ve yatak, giysi dolabı, masa ve sandalyeler gibi ihtiyaçlar karşılanmıştır. Odada banyo ve wc içeren ıslak hacim bulunmasına karşın engelli kullanıcılar için bir düzenleme yapılmadığı görülmektedir. Pencere açıklığının dar ve yatma alanına uzak olması mekânın gün ışığından yaralanma olanağını azaltmaktadır. Bu durum ise mekânı kullanan yaşlı üzerinde olumsuz etkilere yol açabilir.

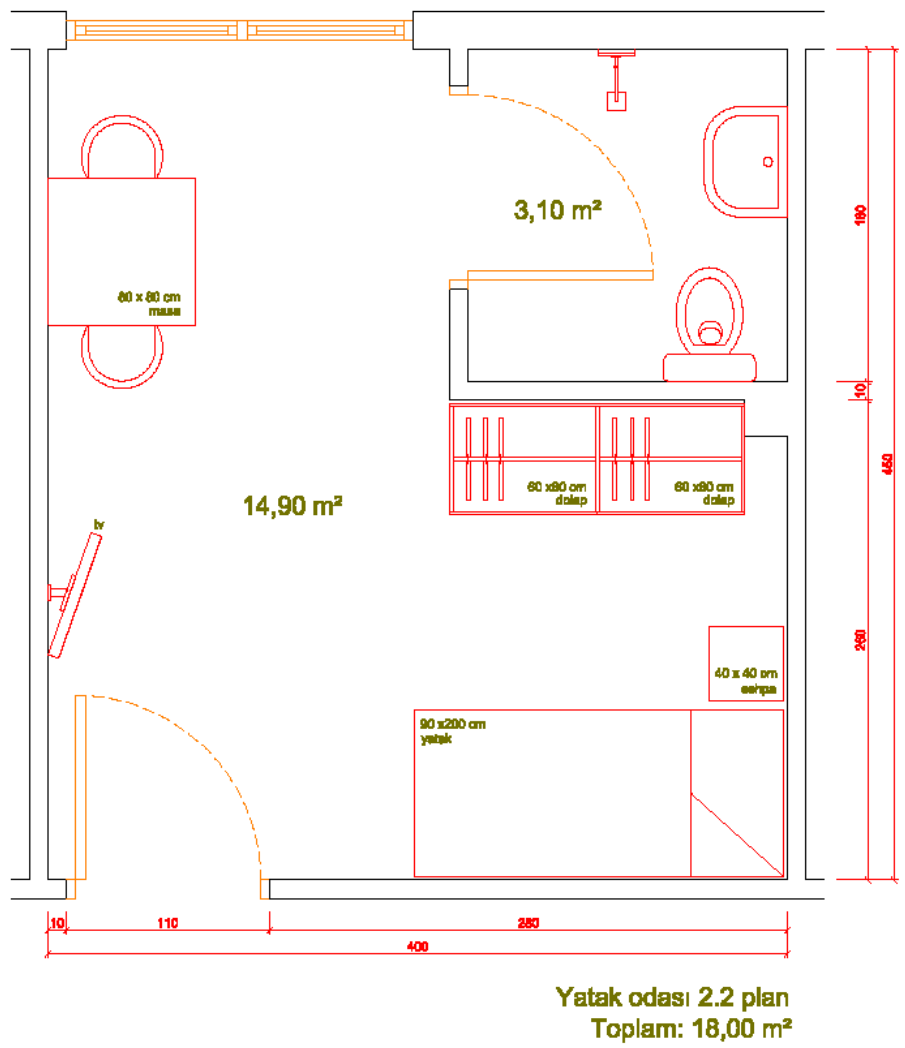

Şekil 10. 2 Numaralı Huzurevi Tek Kişilik Yatak Odası Planı (Kaynak: Yazarın Kişisel Arşivinden)

Şekil 11 'te 2 Numaralı Huzurevi'ne ait üç kişilik yatak odası planı gösterilmiştir. Oda 28,43 m2 yatma ve yaşam alanı ve 4,09 m2 banyo ve wc içeren ıslak hacimden olmak üzere toplam 32,52 m2 alandan oluşmaktadır. Oda 3 kişilik kullanıma göre kurgulanmıştır. Buna göre 3 yatak, giysi dolapları ve masa, sandalyeler mevcuttur. Oda metrekare düzeyinde 3 kişinin rahatça yaşamasına ve bu bağlamda gerekli mahremiyet ve kişiye özel yaşam alanlarının oluşmasına olanak sağlamamaktadır. Bu durumda yaşlı bakımında önemle vurgulanan bir konu olan yaşlıların ev ortamı ve rahatlığında desteklenmesi konusu dikkate alınmamıştır. Ayrıca ıslak hacimde de olası engelli kullanıcılara yönelik bir düzenleme olmadığ 1 görülmektedir. Bunun yanı sıra odada mevcut olan pencere açıklığı yeterli gün 1 şı̆̆1 girişi için uygundur.

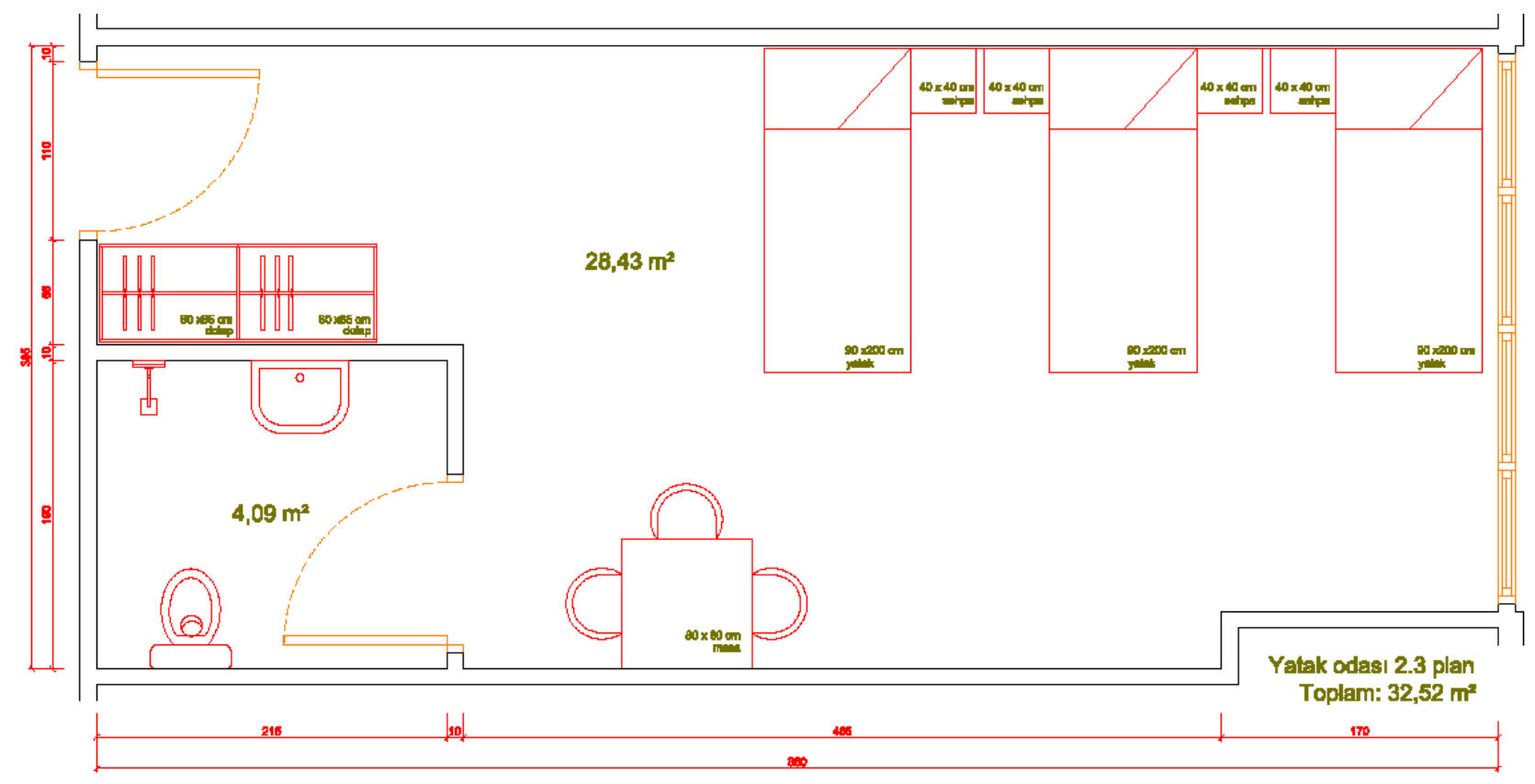

Şekil 11. 2 Numaralı Huzurevi Üç Kişilik Yatak Odası Planı (Kaynak: Yazarın Kişisel Arşivinden) 
Şekil 12'de 2 Numaralı Huzurevi’ne ait iki kişilik oda görseli gösterilmektedir. Yataklar hasta ve engelli kullanımına uygun değildir. Öyle ki, hasta, yaşlı ve engelli kullanımına uygun ortopedik ve hareket ettirilebilir yataklar mevcuttur ve böyle kurumlarda bu tip yataklar kullanılmalıdır. Yatağın yanında yaşlı kişinin olası durumlara karşı kullanabileceği acil çağrı butonu bulunmaktadır. Oda içerisinde kullanılan mobilyalar sivri köşelere sahiptir. Bu tehlikeli bir ortam oluşmasına sebep olmaktadır. Bunun yerine oval köşelere sahip mobilyalar kullanıı açısından daha güvenli olacaktır. Kullanılan renklerin ve desenlerin ise koyu ve baskın olmasından dolayı karanlık ve kasvetli bir ortam oluştuğu görülmektedir. Kullanılan renk ve desenlerin herkese hitap edecek nitelikte olmaması da bazı kullanıcıların yaşadığı mekânı benimsememesine ve yaşadığı yerden memnun olmamasına sebep olabilir. Bunun yanı sıra zemin malzemesinin doğru tercih edildiği görülmektedir.

Şekil 13'de 2 Numaralı Huzurevi'ne ait oda görseli gösterilmektedir. Buna göre resimde görünen giysi dolabı ve yatak arasında kalan mesafe çok dardır. Öyle ki, dolabın kapağının açılması halinde hiç mesafe kalmayacağı görülmektedir. Engelli kullanıcıların bu şekilde yerleştirilmiş bir dolabı kullanması mümkün değildir. Engeli olmayan yaşlı kullanıcılar açısından da dolabı kullanmak oldukça zordur.
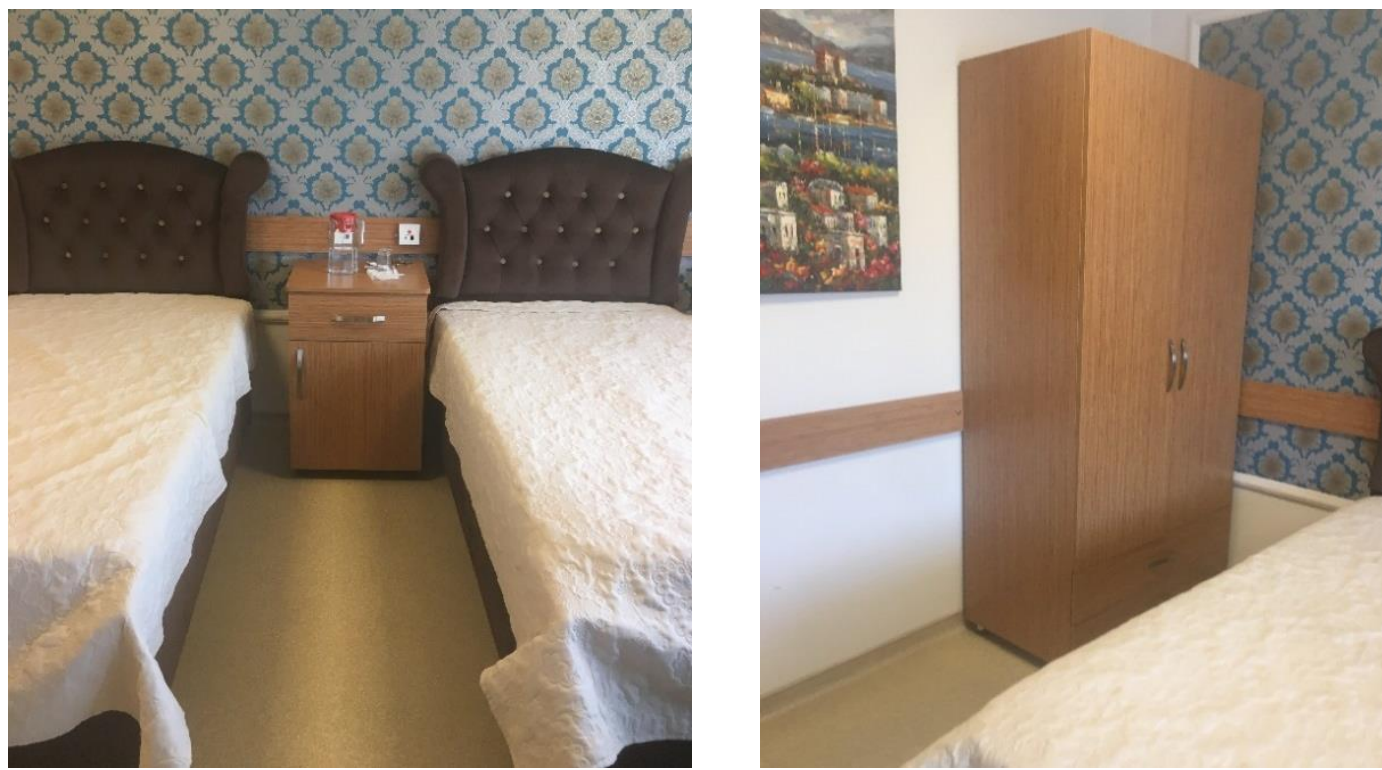

Sekil 12-13. 2 Numaralı Huzurevi İki Kişilik Oda Görseli (Kaynak: Yazarın Kişisel Arşivinden)

Şekil 14'de 2 Numaralı Huzurevi'ne ait ıslak hacim ve tuvalet gösterilmektedir. Tuvaletin yanında kullanılan engelli kullanıcılara yönelik tutunma barı tek başına yetersizdir. Engelli kullanıcılara yönelik daha fazla eleman ve tutunma barı bulunmalıdır. Yer döşemesinde kullanılan seramik karolar kaygan özelliktedir ve tehlike arz etmektedir. Diğer taraftan, sslak hacimde acil çağrı butonu olmadığı görülmektedir.

Şekil 15'de 2 Numaralı Huzurevi'ne ait ıslak hacim mekânı lavabosu gösterilmektedir. Bu alanda engelli kullanıcılara yönelik hiçbir düzenleme yapılmadığı görülmektedir. Lavabo yüksekliğinin tekerlekli sandalye kullanıcısına uygun olması gerekmektedir. Ayrıca lavabo yanına tutunma barı yerleştirilmemiştir. Ayna engelli kullanıcılar açısından oldukça kullanışsızdır ve ıslak hacimde acil çağrı butonu olmadığı görülmektedir.
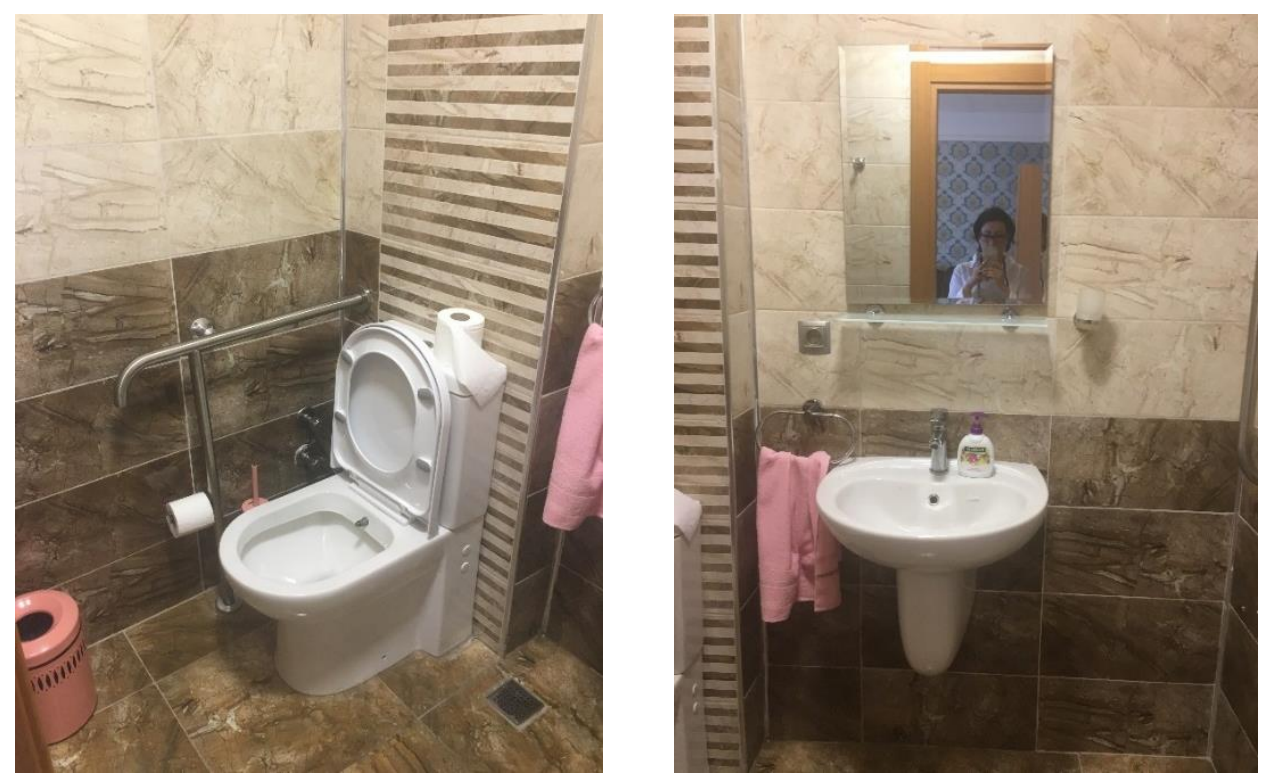

Şekil 14-15. 2 Numaralı Huzurevi Islak Hacim Mekânı Tuvalet ve Lavabo Görseli (Kaynak: Yazarın Kişisel Arşivinden) 
Şekil 16'da 3 Numaralı Huzurevi'ne ait tek kişilik yatak odası planı gösterilmektedir. Oda 12,13 m2 yatma ve yaşam alanı ile $2,57 \mathrm{~m} 2$ sslak hacim olmak üzere toplam $14,70 \mathrm{~m} 2$ toplam alandan oluşmaktadır. Odanın tek kişilik kullanıma ve engelli dolaşımına uygun olduğu görülmektedir. Odada kişinin kullanabileceği yatak, giysi dolabı, oturma elemanı ihtiyaçları mevcuttur. Yeterli pencere açıklığının sağlanmış olması da kişinin dış mekânla ilişki kurmasını ve gün ışığının olumlu etkilerinden yararlanmasına olanak sağlamaktadır. Buna karşın ıslak hacimde olası engelli kullanıcılar için düzenleme olmadığı görülmektedir. Bu durum önemli sorunlara ve engelli kullanıcı açısından çeşitli zorluklara sebep olacak bir eksikliktir.

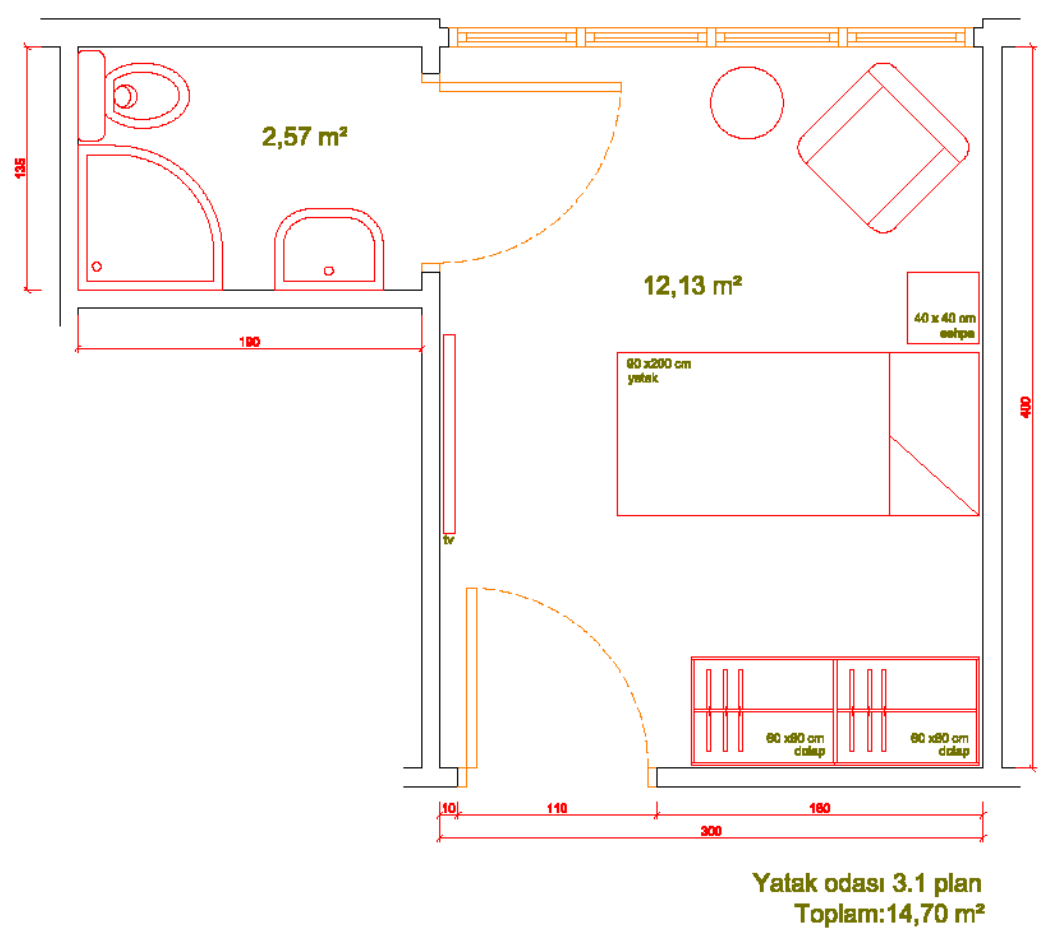

Şekil 16. 3 Numaralı Huzurevi Tek Kişilik Yatak Odası Planı (Kaynak: Yazarın Kişisel Arşivinden)

Şekil 17'de 3 Numaralı Huzurevi'ne ait çift kişilik yatak odası planı gösterilmektedir. Oda 17,43 m2 yatma ve yaşam alanı ile 4,40 m2 1slak hacim alanı olmak üzere toplam 21,83 m2 alandan oluşmaktadır. Odada iki kişinin kullanabileceği yatak, giysi dolapları ve oturma elemanları mevcuttur. Pencere önüne konumlandırılmış yatak ve oturma elemanının engelli kullanıcıların erişimine engel teşkil edebileceği görülmektedir. Ayrıca yine ıslak hacimde bu kullanıcılara yönelik bir uygulama bulunmadığı görülmektedir.

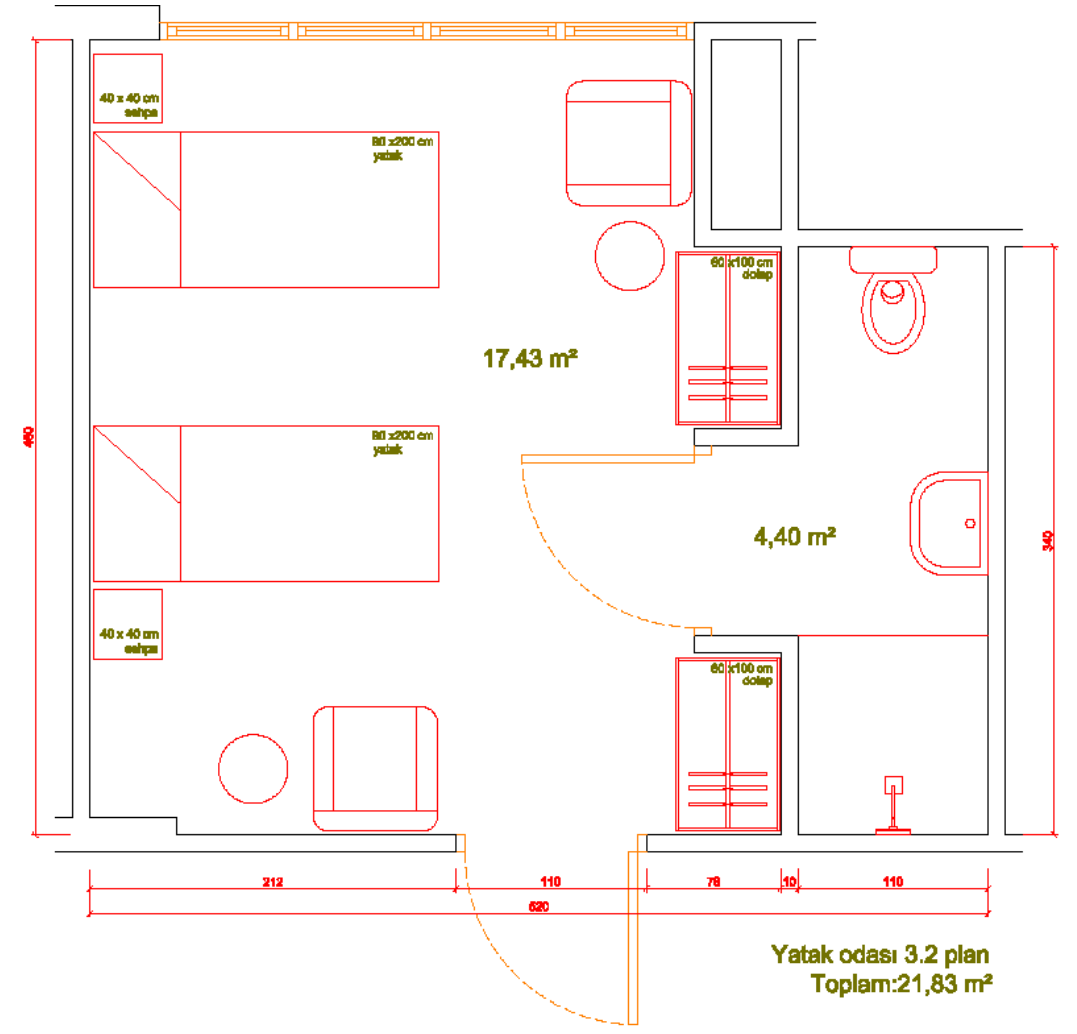

Şekil 17. 3 Numaralı Huzurevi Çift Kişilik Yatak Odası Planı (Kaynak: Yazarın Kişisel Arşivinden) 
Şekil 18'de 3 Numaralı Huzurevi'ne ait tek kişilik oda gösterilmektedir. Diğer İstanbul örnekleriyle karşılaştırıldığında standartlara en uygun örneğin bu olduğu gözlemlenmektedir. Öyle ki, geniş pencerelere sahip, cephede güneş kırıcıları olan, güneş ışığı alan, engelli dolaşımına uygun, zemin malzemesi doğru tercih edilmiş ve acil çağrı butonu gibi önemli elemanlar mevcuttur.

Şekil 19'da 3 Numaralı Huzurevi’ne ait iki kişilik oda gösterilmektedir. Bu oda hasta ve yaşlı kişilere göre düzenlenmiştir. Öyle ki, yataklar yan taraflarında bariyerleri bulunan, sırt bölümü hareket ettirilebilen hastane tipi yataklardır. Çeşitli tıbbi cihazlar odada bulunmaktadır. Ancak bu tip odalarda gerekli mahremiyetin sağlanması için yatakların arasında bir ayırıı bulunması gerekmektedir. Odada ki pencere açıklığı ve gün ışığı seviyesi uygundur
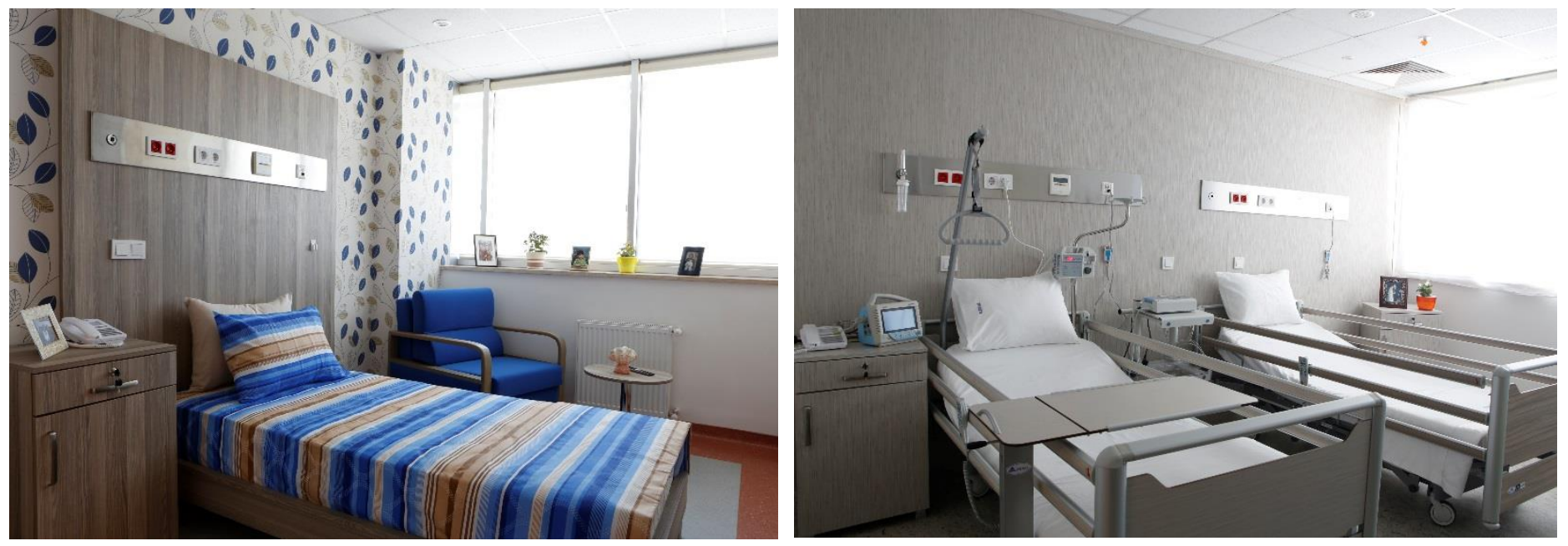

Şekil 18-19. 3 Numaralı Huzurevi Tek ve Çift Kişilik Oda Görseli (Kaynak: Yazarın Kişisel Arşivinden)

\subsubsection{Brüksel Örnekleri}

Çalışma kapsamında Brüksel bölgesinden 3 ayrı huzurevi seçilmiştir. Bunlar; Senior Assist Mouterij Huzurevi, Senior Assist Londerzeel Huzurevi ve Senior Assist Pleiades Huzurevidir. Seçilen huzurevleri birebir incelenmiş, yerinde yapılan ölçümler ve tespitler sonucunda yatak odası mekânlarının planlama şemaları çıkarılmıştır. Mekânlara ait planlar aşağıda sunulmuştur.

Şekil 20'de Brüksel Senior Assist Mouterij Huzurevi'ne ait çift kişilik yatak odası planı gösterilmektedir. Oda 24,06 m2 yatma ve yaşam alanı ile $3,71 \mathrm{~m} 2$ slak hacimden olmak üzere toplam $27,77 \mathrm{~m} 2$ alandan oluşmaktadır. Oda çift kişiliktir ve iki kişinin kullanımına uygun yatak, giysi dolabı, masa ve sandalyeler içermektedir ve engelli kullanıcı dolaşımına uygun şekilde yerleştirilmiştir. Islak hacimde wc ve banyo alanlarında engelli kullanıcıya uygun düzenlemeler yapıldığı görülmektedir. Buna göre engelli kullanıcılar için tutunma barları bulunmaktadır ve duş alanı tekerlekli sandalyenin girebileceği şekilde tasarlanmıştır. Verilen kapı açıklıkları da tekerlekli sandalye geçişi için uygundur. Pencere açıklıklarının iki cephede de bırakıldığı görülmektedir. Bu durum gün ışığından daha fazla yararlanma olanağ 1 vermektedir.

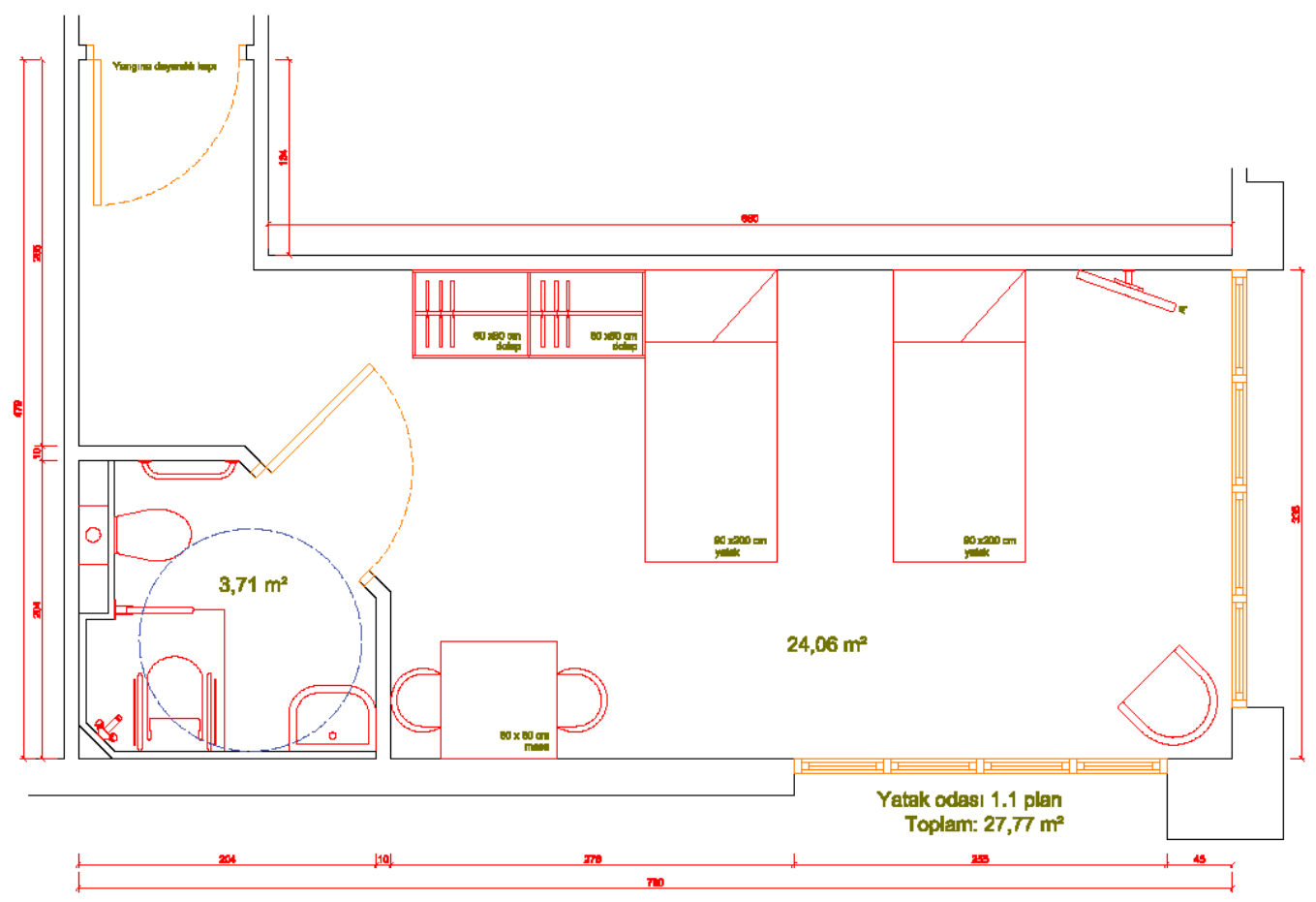

Şekil 20. Senior Assist Mouterij Huzurevi Çift Kişilik Yatak Odası Planı (Kaynak: Yazarın Kişisel Arşivinden) 
Şekil 21'da Senior Assist Mouterij Huzurevi'ne ait tek kişilik yatak odası planı gösterilmektedir. Oda 21,11 m2 yatma ve yaşam alanı ile 3,71 m2 sslak hacim olmak üzere toplam 24,82 m2 alandan oluşmaktadır. Oda tek kişinin kullanımına uygun yatak, giysi dolabı, oturma elemanı, masa ve sandalyeler içermektedir. Islak hacimde wc ve banyo alanlarında engelli kullanıcıya uygun düzenlemeler yapıldığı görülmektedir. Buna göre engelli kullanıcılar için tutunma barları bulunmaktadır ve duş alanı tekerlekli sandalyenin girebileceği şekilde tasarlanmıştır. Verilen kapı açıklıkları da tekerlekli sandalye geçişi için uygundur.

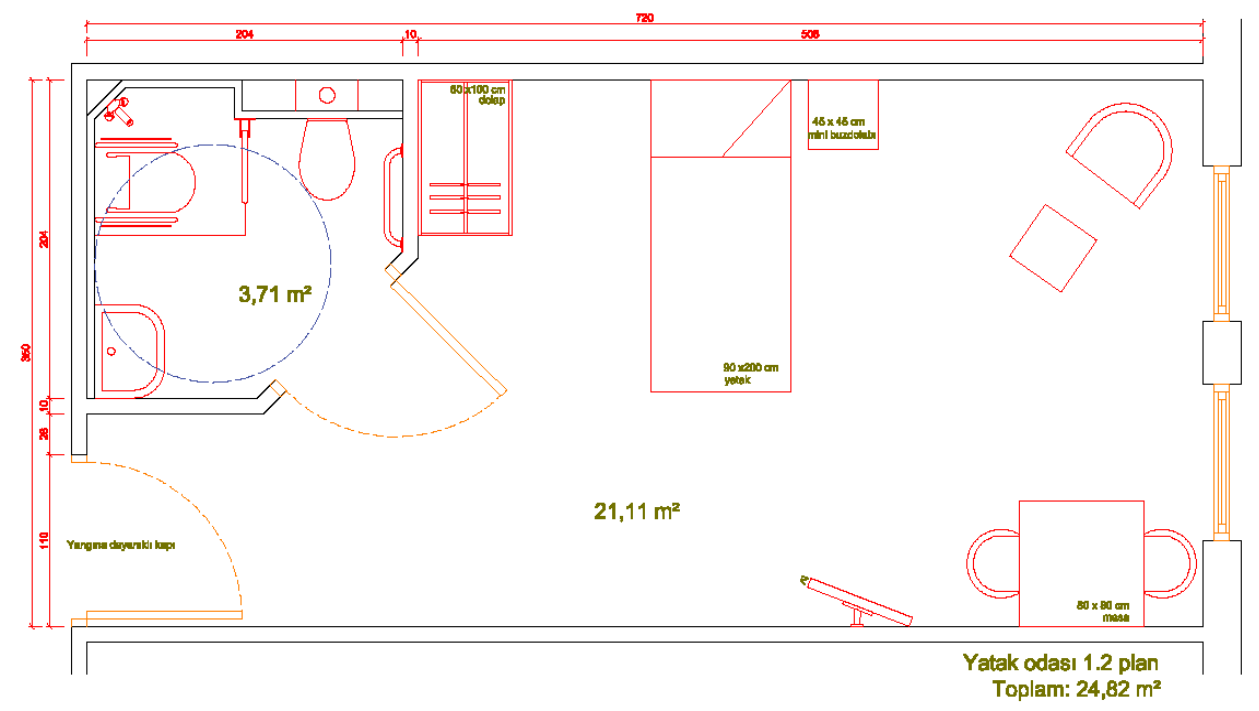

Şekil 21. Senior Assist Mouterij Huzurevi Tek Kişilik Yatak Odası Planı (Kaynak: Yazarın Kişisel Arşivinden)

Şekil 22'de Senior Assist Londerzeel Huzurevi’ne ait tek kişilik yatak odası planı gösterilmektedir. Oda 17,05 m2 yatma ve yaşam alanı ile 4,48 m2 ıslak hacim olmak üzere toplam 21,53 m2 alandan oluşmaktadır. Odada tek kişinin kullanımına uygun yatak, giysi dolabı, oturma elemanı, masa ve sandalye mevcuttur. Islak hacimde wc ve banyo alanlarında engelli kullanıcıya uygun düzenlemeler yapıldığı görülmektedir. Buna göre engelli kullanıcılar için tutunma barları bulunmaktadır ve duş alanı tekerlekli sandalyenin girebileceği şekilde tasarlanmıştır. Islak hacim içi dolaşım da engelli kullanıcılara uygundur. Lavabonun bağlı olduğu panel açılıp kapanabilir özelliktedir. Bu şekilde engelli kullanıcının ihtiyaçlarını daha rahat karşılaması sağlanmıştır. Kapı açıklıkları da bu açıdan uygun özellik taşımaktadır. Geniş pencere açıklığı da gün ışığından mümkün olduğunca çok faydalanmaya olanak sağlamaktadır. Pencereden gün ışı̆̆ı güneş kırıcılar sayesinde gün içi rahatlıkla ayarlanabilir durumdadır.

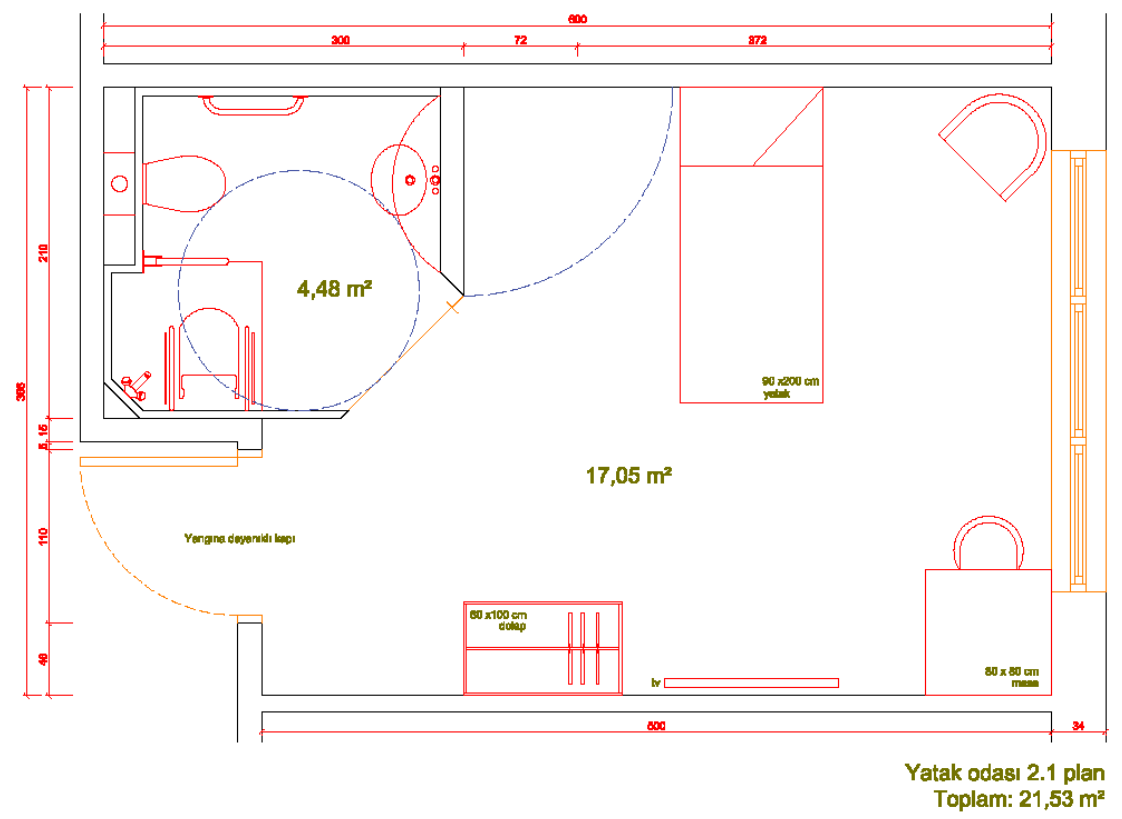

Şekil 22. Senior Assist Londerzeel Huzurevi Tek Kişilik Yatak Odası Planı (Kaynak: Yazarın Kişisel Arşivinden)

Şekil 23'de Senior Assist Londerzeel Huzurevi’ne ait tek kişilik yatak odası gösterilmektedir. Oda yaşlı bakım evleri standartlarına son derece uygundur. Pencere açıklıkları geniş ve gün 1şı̆̆ı girişine mümkün olduğunca olanak sağlamaktadır. Pencereden gün ışığı güneş kırıcılar sayesinde gün içi rahatlıkla ayarlanabilir durumdadır. Yatak, yaşlı ve hasta kullanıcılara uygundur. Pencere yanında kullanılan oturma elemanı kullanıcıyı rahat ettirecek ve dişarıyı izlemesine olanak sağlayacak özelliktedir. Oda tekerlekli sandalye dolaşımına uygundur. Zemin döşemesi kaymaz ve yumuşak özelliktedir. Odada tercih edilen renkler oldukça sade ve dinlendiricidir. Bu sayede kullanıcı odasını istediği şekilde kişiselleştirebilecektir. Acil çağrı butonu gibi önemli elemanlar mevcuttur. 
Şekil 24'de Senior Assist Londerzeel Huzurevi'ne ait sslak hacim mekânı gösterilmektedir. Bu örnekte 1slak hacim ile yatma alanını birbirinden ayıran panelin hareket ettirilebilir özellikte olduğu görülmektedir. Bu engelli kullanıcı açısından kolaylık sağlamaktadır. Ayrıca iki mekânın birbirinden ayrıldığı noktada hem zemin bir geçiş olduğu görülmektedir. Bu engelli kullanımı açısından çok doğru bir uygulamadır. Islak hacim zemin döşemesi de yine kaymaz ve yumuşak özelliktedir. Tuvalet ve duş alanlarında yeterli sayıda tutunma barı mevcuttur. Ayrıca acil çağrı butonu da bu alanda mevcuttur.
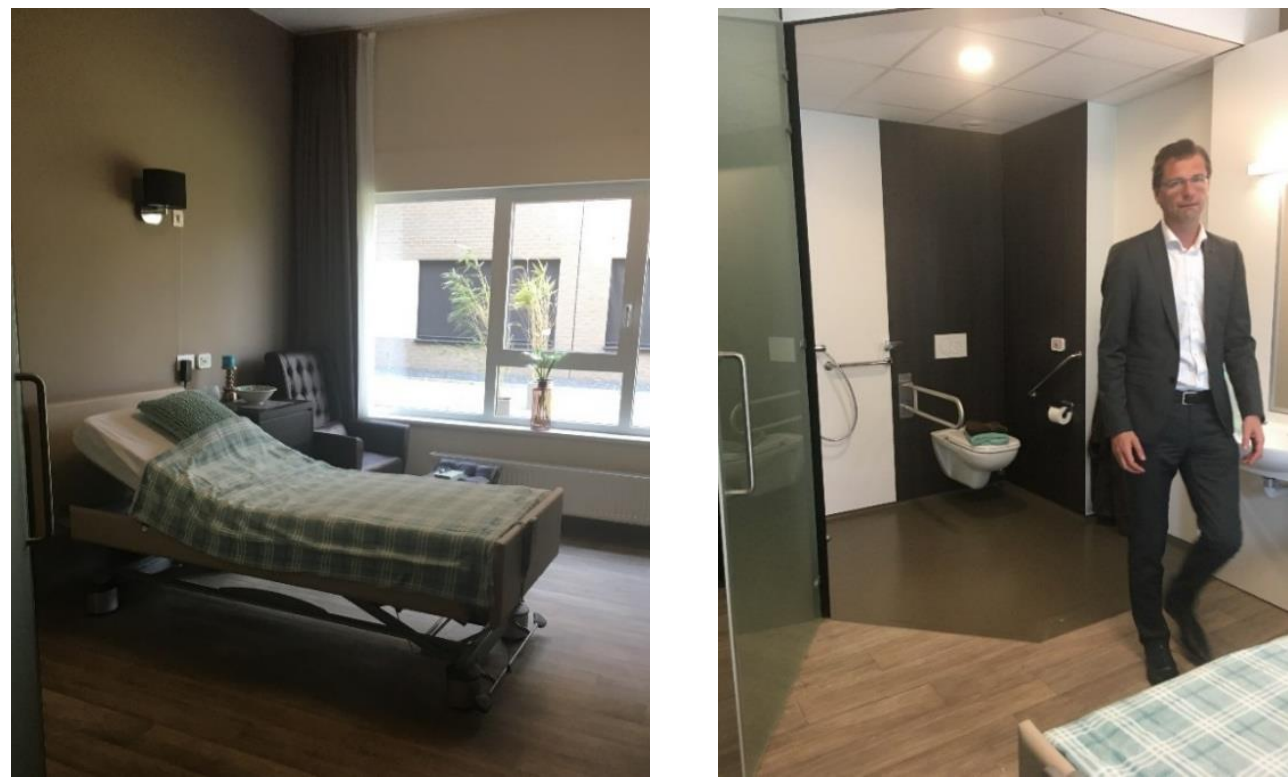

Şekil 23-24. Senior Assist Londerzeel Huzurevi Tek Kişilik Yatak Odası ve Islak Hacim Mekânı Görseli (Kaynak: Yazarın Kişisel Arşivinden)

Şekil 25'de Senior Assist Londerzeel Huzurevi'ne ait sslak hacim mekânı lavabosu gösterilmektedir. Lavabonun bağlı olduğu panel hareket ettirilebilir özelliktedir. Lavabo yüksekliği engelli kullanıcı açısından doğru ölçülerdedir. Ayrıca örnekte aynanın kullanım şekli de engelli kullanıcıya uygundur. Lavabo armatürleri de bu kullanıcılara uygun şekilde seçilmiştir.

Şekil 26'de Senior Assist Londerzeel Huzurevi'ne ait sslak hacim mekânı duş alanı gösterilmektedir. Bu alanda kullanılan engelli kullanıcılara yönelik tutunma barlarının yeterli olduğu görülmektedir.
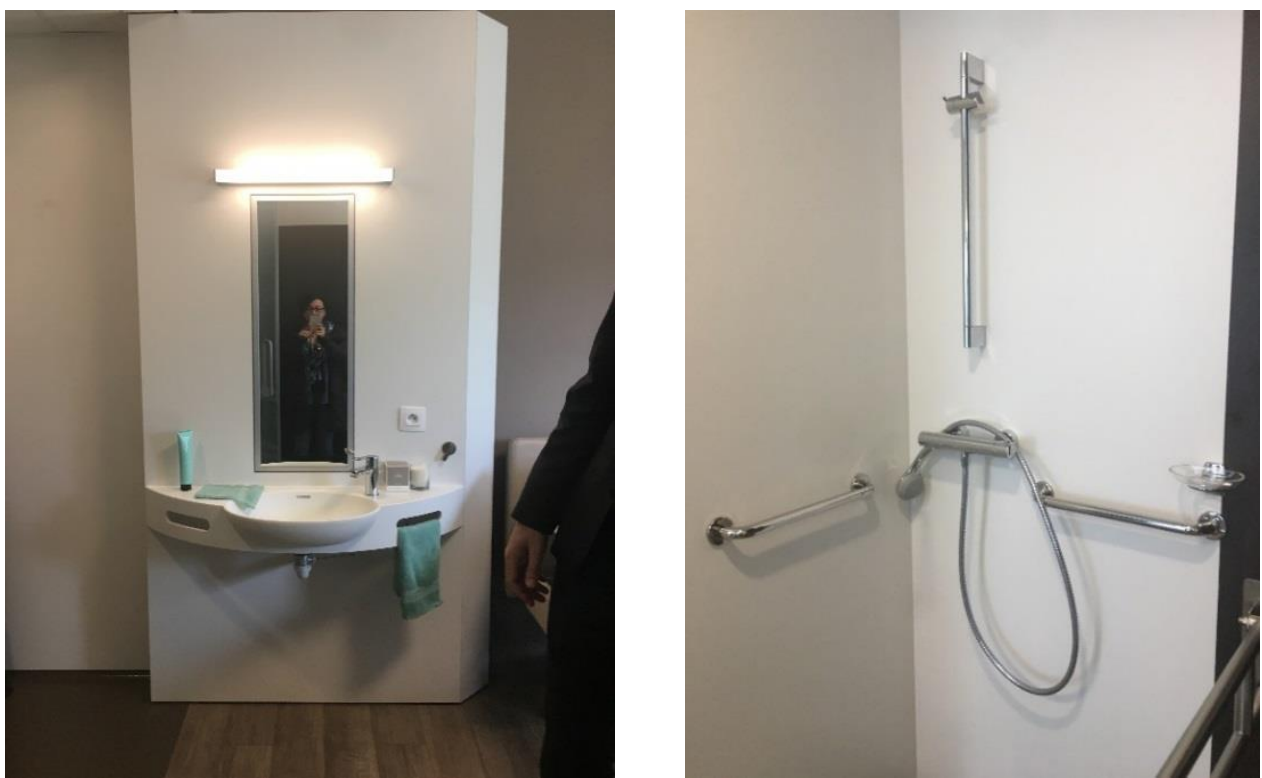

Şekil 25-26: Senior Assist Londerzeel Huzurevi Islak Hacim Mekânı Lavabo Görseli (Kaynak: Yazarın Kişisel Arşivinden)

Şekil 27'de Brüksel Senior Assist Huzurevi'ne ait daire planı gösterilmektedir. Yaşlı bakım kurumları konusunda gelişen anlayışlar, yaşlıları mümkün olduğunca ev ortamında destekleme konusunun önemini ortaya çıkarmıştır ve bu örnekler yaygınlaşmaktadır. Bu örnekte bu tip bir anlayışla yapılmıştır ve yaşının kendi ev ortamını sağlayabilmesi için daire mantığıyla planlanmıştır. Örnek oda planı, yatma ve oturma kısımları ayrılmış ev görünümünde birimlerdir. Aynı zamanda birkaç çeşit alternatif oda planı sunulmaktadır. Oda planı stüdyo daire biçiminde ve 33,49 $\mathrm{m} 2$ toplam alana sahiptir, otel ve hastane odasından çok farklılaştığ görülmektedir. Yatak ve yaşam mekânı ayrı olarak belirlenmiştir. Banyo ve wc yaşlıya uygun tasarımdadır. Depo düşünülmüş ve tek kişilik birimlerdir. İstenildiği zaman yalnız kalınabilen, istenildiği zaman da topluma veya aktivitelere katılımın mümkün olduğu görülmektedir. 


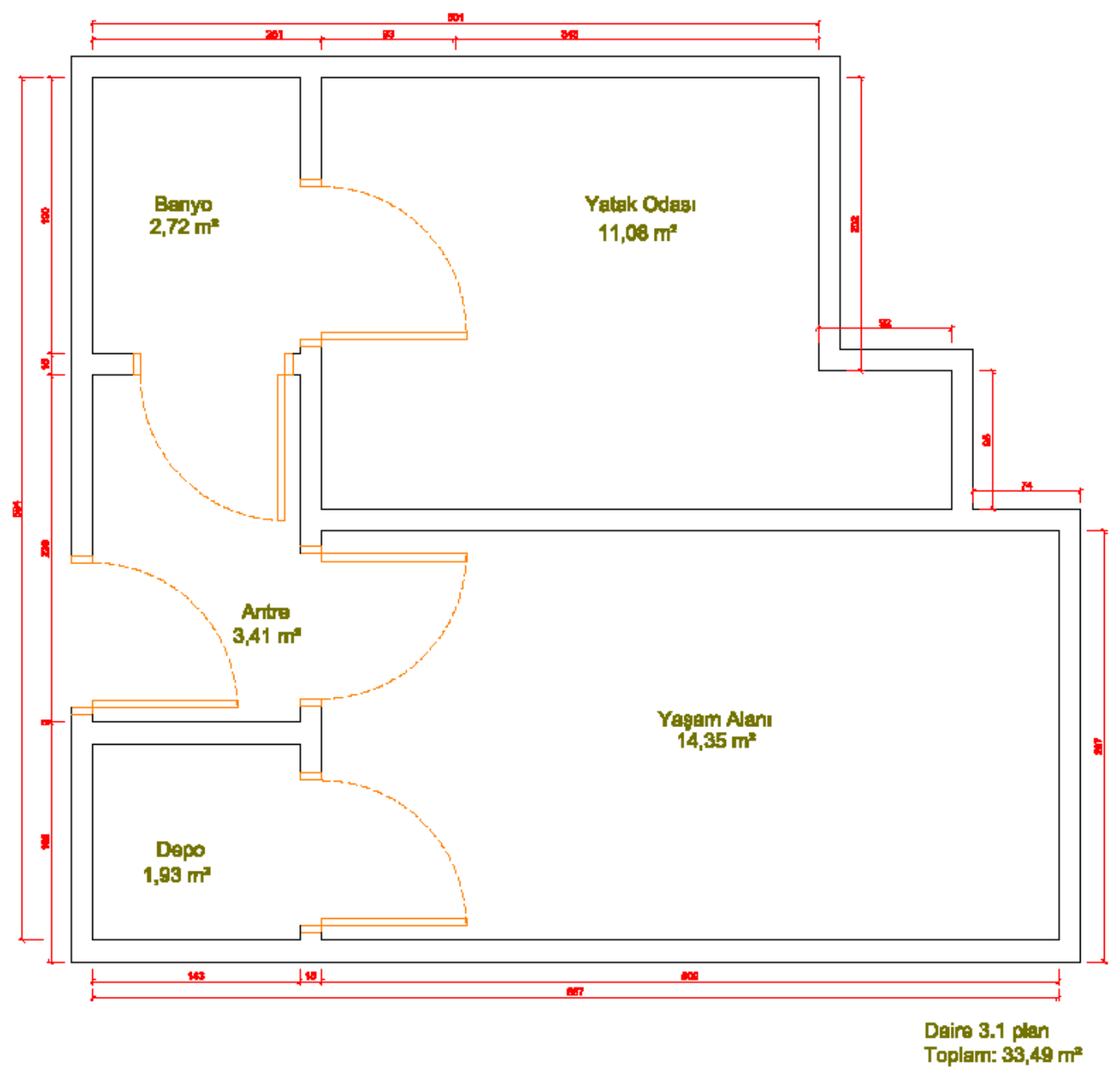

Şekil 27. Senior Assist Pleiades Huzurevi Daire Planı (Kaynak: Yazarın Kişisel Arşivinden)

Şekil 28'de Senior Assist Pleiades Huzurevi'ne ait daire örneği gösterilmektedir. Bırakılan kapı açıklıklarının tekerlekli sandalye geçişine uygun olduğu görülmektedir. Ayrıca koridorda bu kullanıcılara yönelik tutunma barı konulduğu görülmektedir. Yaşlı kişilerin hem kendi ev ortamlarında hem de kontrol altında yaşayabilecekleri bu örnekler yaygınlaşmaktadır.

Şekil 29'da Senior Assist Pleiades Huzurevi'ne ait daire 1slak hacim mekânı gösterilmektedir. Zemin döşemesinin kaymaz özellikte olduğu görülmektedir. Duş alanında engelli kullanıcılara yönelik tutunma barları mevcuttur. Lavabo ve ayna da aynı şekilde bu kullanıcılara uygun olarak kullanılmıştır.
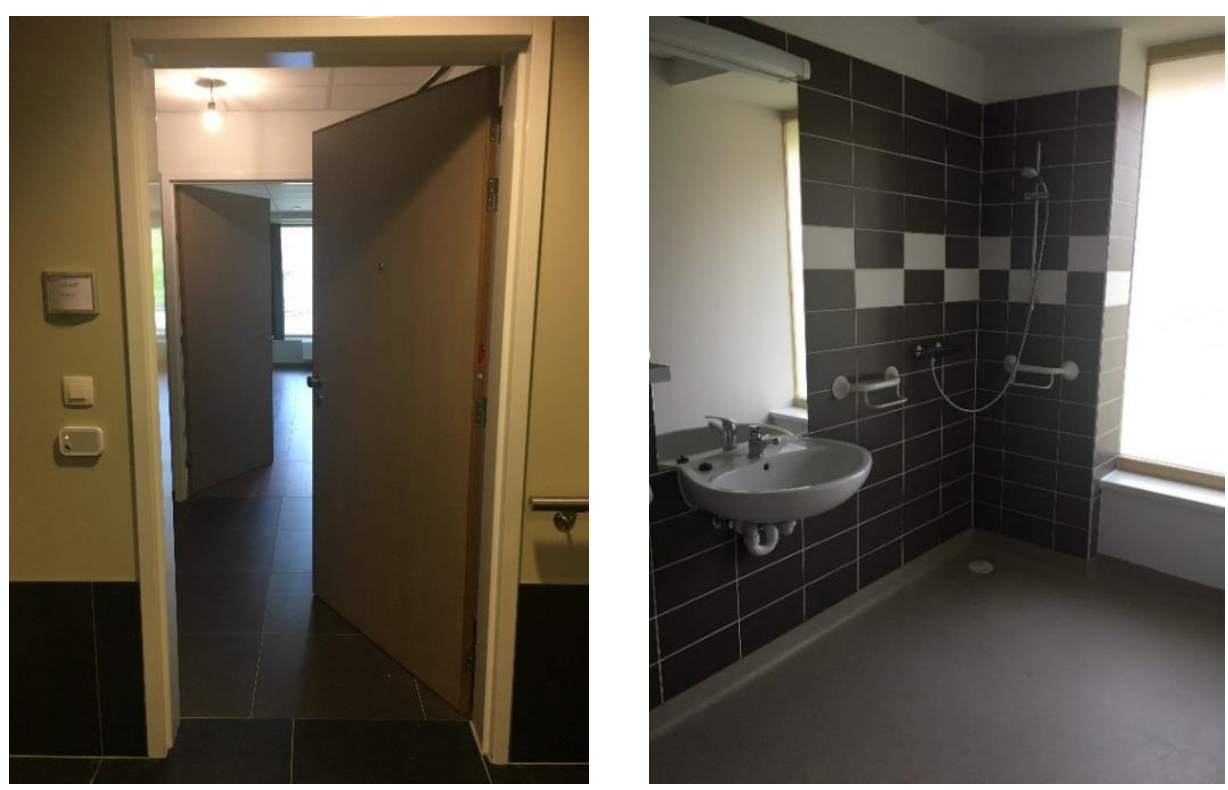

Şekil 28-29. Senior Assist Pleiades Huzurevi Daire ve Islak Hacim Mekânı Görseli (Kaynak: Yazarın Kişisel Arşivinden) 


\section{Sonuç}

Bu çalışmada; Türkiye (İstanbul) ve Belçika (Brüksel) daki özel kurum/şahıslara ait olan huzurevleri ve yaşlı bakım merkezleri standartları kapsamında örnek yatak odası mekânlarında yapılmış olan incelemeler (Zerrin Funda Ürük kişisel analizler, Nisan 2017) sonucu elde edilen veriler sayesinde, huzurevinde kalan yaşlıların ev ortamına en çok özdeşleştiği ve yoğunlukla kullandığı yatak odası mekânının planlama esnasında dikkat etmemiz gereken unsurlar tespit edilerek, gelecekte yaşlılar için daha yaşanabilir huzurevleri tasarlanmasına fayda sağlayacak öneri çalışmaları sunulmuştur. İki bölgedeki huzurevlerinde tek kişilik, çift kişilik veya üç kişilik örnek yatak odası mekânları üzerinde çalışılmış ve mekanların bölgesel ve kültürel standartlara göre uygunluk incelemesi yapılmıştır. Gözlemlenen bu durum çerçevesinde aşă̆ıda belirtilen şu sonuçlar elde edilmiş̧ir.

1. Türkiye yaşlı bakımı konusunda her ne kadar önemli bir geçmişe sahip olsa da maalesef ülkemizde bu hizmetin günümüz şartlarına ve $A B$ standartlarına uygun yapılmadığı gözlenmiştir. Yaşlılık sorunları ile Türkiye'den çok daha önce karşılaşmış ve çözüm projeleri geliştirmiş, $\mathrm{AB}$ standartlarına sahip ülkelerden biri olan Belçika'daki huzurevlerinin yapılan tespitler sonucu; yaşlılara sağladığı hizmetler ve mekanların yaşamsal kalitelerinin yüksek düzeyde olduğu tespitlenmiştir.

2. AB standartlarına sahip ülkelerin hızla terk ettiği klasik huzurevi konseptinin maalesef halen ülkemizde uygulandığı gözlenmiştir. Yapılan araştırmalar sonucu huzurevlerinde kalan yaşlıların kendi ev ortamlarını ve orada geçirdikleri yaşamı ve anılarını özledikleri görülmüştür. Bunun için huzurevlerindeki mekanların tasarımları yapılırken yaşlılara kendisini misafir gibi hissetmeyecekleri ve kendi evlerinde kalıyor duygusunu yaşatacağı mekânların tasarlanmasına dikkat edilmesi gereklidir.

3. Huzurevleri ve yaşlı bakım merkezleri anlayışı ve şartları geçmişten günümüze büyük gelişmeler göstermiştir ve göstermektedir. Buna göre eskiden yaşlıların kalabalık şekillerde, koğuş mantı̆̆ıyla bakıldıkları mekânlarda bugün yaşlıların bireysel ihtiyaçlarına önem veren, bireysel ve insani şartları ve unsurları gözeten mekânlar tasarlanmaktadır. Yatak odaları da bu süreç içerisinde oldukça gelişim göstermiştir. Son zamanlarda yaşlının kendi ev ortamı ve rahatlığında bakılması gerektiği anlayışı yaygınlaşmıştır. Huzurevleri de bu bağlamda oturma alanlarının, televizyonun, buzdolabının, kişisel ıslak hacim mekânlarının, vb. içinde bulunduğu yatak odası mekânlarına yönelmişlerdir.

4. Belçika-Brüksel örneklerinde gördüğümüz üzere yaşlıların yaşam standartlarını daha kaliteli olarak yükseltecek ve evrensel tasarıma uygun yatak odası mekanları tasarlandığı gözlenmiştir. Gözlemler sonucu;

- Yatma ve sslak hacim mekânı içerisinde kullanılan mobilyalar, yüzey malzemeleri ve aydınlatma ürünlerinin mekânsal şartlara, evrensel tasarım kriterlerine ve engelli kullanıcılara uygunluğu,

- Yaşlıların daha iyi bir yaşam sürdürebilmesi için özel yatak ve sslak hacim tasarımlarının yapıldığı,

- Yatak odaları genellikle tek kişilik yapıldığı ve her odanın kendine ait ıslak hacim wc-banyo mekânı olduğu ve yaşlılara uygun tasarlandığ 1 ,

- Wc-Banyo mekânında ve yatak başucunda hemşire butonlarının evrensel tasarım standartlarına uygun olarak yerleştirildiği,

- Yatak odası pencerelerinin yüksekliklerinin oturma düzlemine göre ayarlandığı,

- Kullanılan mobilyaların köşelerinin sivri olmaması, yuvarlak hatlarda ve mekân içi mobilyalarda kullanılan renklerin daha sıcak ve ev ortamını yansitan özellikte olduğu,

- Duvarların tek renk boya dışında yaşlıların psikolojine uygun olarak farklı desenlerde duvar kağıtları ile kaplanmış olduğu,

- Yaşlı bakım kurumlarında yeni gelişen anlayışlar sonucu yaşlıları mümkün olduğunca ev ortamı psikolojisini destekleme konusunun önemini ortaya çıarmak için yatak odalarının haricinde huzurevi konsepti içerisinde $1+1$ daire tipi yaşama mekanları yapıldığı görülmüştür. Bu daire kullanıcıları bağlı olduğu huzurevinin sosyal hizmetlerinden komple yararlanabilmektedirler.

5. Türkiye-İstanbul örneklerinde gördüğümüz üzere ise; $\mathrm{AB}$ standartlarına sahip ülkelerin hızla terk ettiği klasik huzurevi konseptinin maalesef halen ülkemizde uygulandığı gözlenmiştir. Gözlemler sonucu;

- Yatma ve ıslak hacim mekânı içerisinde kullanılan mobilyalar, yüzey malzemeleri ve aydınlatma ürünlerinin mekânsal şartlara, evrensel tasarım kriterlerine ve engelli kullanıcılara tam olarak uygunluğunda sıkıntı olduğu,

- Tek kişilik oda sayısının azlığı ve m2 kullanımı olarak doğru tasarlanmamış olduğu ve daha çok 2 ya da 3 kişilik odalarda yaşlıların kaldığı,

- Her odanın kendine ait ıslak hacim wc-banyo mekânı olmadığı,

- Belli orandaki yaşlı nüfusun yataklarının standart bazalı yataklardan oluştuğu,

- Wc-Banyo mekânında ve yatak başucunda hemşire butonlarının evrensel tasarım standartlarına uygun olarak yerleştirildiği,

- Yatak odası pencerelerinin açılımı ve yüksekliklerinin iç mekân düzenine uygun olarak ayarlanmadığı,

- Kullanılan mobilyaların yaşlı ve engelli bireylere uygun olarak tasarlanmamış olması,

- Yatak odası mekânında ev ortamını hissettirecek ve aidiyet duygusunu arttıracak özelliklerin olmadığı,

6. Elde edilen sonuçlardan Türkiye'deki huzurevleri ile ilgili uluslararası standartlara bağlı ama kültürel normlara sadık kalınarak yeni bir yönetmelik üzerinde çalışılması önerilmektedir. Huzurevi tasarımları yapılırken hedef ise; mekânsal kalitenin iyi olduğu bu yapıların Türkiye genelinde yaygınlaşması olmalıdır ve bunun için Türkiye'deki huzurevlerinin yaşlının yaşam kalitesini maksimum ölçüde sürdürmek ve geliştirmek için modernize edilmesi gerekmektedir.

\section{Kaynakça}

Aile ve Sosyal Politikalar Bakanlığı, Engelli ve Yaşlı Hizmetleri Genel Müdürlüğü, Türkiye'de Yaşlıların Durumu ve Yaşlanma Ulusal Eylem Planı Uygulama Programı, Ankara, 2013

Berkin, G., Özcan, U., (2017), “Oturmanın Ergonomisi”, Yapı Dergisi (ISSN: 1300-3437, DAAI-Design and Applied Arts Index), Say1: 426, s:140. 
Cai, H., Zimring, C., (2013), "Understanding cultural differences in nursing unit design with the support of spaces yntax analysis are

Chinese nursing units designs different from their U.S. counter- parts?" In: Kim, Y.O., Park, H.T., Seo, K.W.(Eds.), Proceedings of the Ninth International Space Syntax Symposium.Sejong University, Seoul, pp.1-24.

Charness N., Dijkstra K. (1999), "Age, luminance, and print legibility in homes, offices, and public place”, Human Factors, 41(2), 173193.

Doğan Bulut, Z. (2014). Huzurevlerinde ve evde yaşayan yaşlılarda düşme ile ilişkili risk faktörleri. (Yayımlanmış Yüksek Lisans

Tezi), T.C. Hacettepe Üniversitesi Sağlık Bilimleri Enstitüsü, Ankara

Erkal, S. (2005). Kırıkkale Ovacık mahallesinde yaşayan 65 yaş ve üzeri kişilerin ev kazaları ile karşılaşma durumlarının ve kaza nedenlerinin incelenmesi. Türk Geriatri Dergisi, 8(1): 17-21.

Hedge A.L., Rhodes R. (2010). "Assessment of lighting in independent living facilities and residents' perceptions", Journal of Applied Gerontology, 29(3)

Kutsal Gökçe, Y. (2009). "Yaşlanan Dünyanın Yaşlanan İnsanları" GEBAM Yayınları, Ankara.

Lök, N. \& Akın, B. (2013, Şubat). Domestic environmental risk factors associated with falling in elderly. Iranian Journal of Public

Health, 42(2):120-128.

Mumcu Boğa, N., Özdelikara, A. \& Ağaçdiken, S. (2015, Ocak). Huzurevindeki yaşlı hastalarda düşme davranışlarının belirlenmesi.

Gümüşhane Üniversitesi Sağlık Bilimleri Dergisi, 4(3): 360-372

Özcan, U., Erol, İ., (2018), Organik Mimarlık, Dicle Üniversitesi I Uluslararası Mimarlık Sempozyumu, 4-6 Ekim, Diyarbakır, Türkiye.

Özcan, U., Güngör, S., (2019), " Geleneksel Türk Evi ve Yapısal Özellikleri", İçinde: Kaya, Latif Gürkan (Ed.), 2019, Mimarlık,

Planlama ve Tasarım Alanında Araştırma ve Değerlendirmeler - 2019 Haziran (ISBN: 978-605-7852-93-9), Gece Kitaplığı Yayınevi, İstanbul.

Özel, Y., "Türk Evinde Sokağa Uzanan İç Mekanlar: Çıkmalar”, 3. Uluslararası Uluslararası Sosyal ve Beşeri Bilimler Konferansı, 02 -

05 Mayıs 2019, Berlin, Almanya

Öztürk, T., Ürük, Z. F, Özel, Y., Uzgören, G., "Mekansal Elverişlilik ve Fiziksel Çevre Kalitesi Bağlamında Mekânsal Kalite Analizi”,

2. Ulusal İç Mimari Tasarım Sempozyumu 2018, 06-07 Aralık 2018, Trabzon

Peters Roderick, Nursing Homes Visit, roderick.peters@acalis.com (12.04.2017), zfuruk@gelisim.edu.tr (17.04.2017).

Pülüm, E., Sökmen, Ü.N., Çevik Akyıl, R., Ongun, G. \& Özdemir Cihangir, H. (2018, Ocak). Aydın Huzurevinde Düşme Riski Taşıyan

Yaşlıların Belirlenmesi: Tanımlayıcı Çalışma. İzmir Kâtip Çelebi Üniversitesi Sağlık Bilimleri Fakültesi Dergisi, 3(2): 9-14

Türel, G. (2011) "Yaşlı Barınma Merkezlerinde Tasarımın Gelişmesi”, Yaşlı Sorunları Araştırma Dergisi, Sayı 1, s.28-43.

Uzgören, G., Öztürk, T., Ürük, Z. F, Özel, Y., "Kamusal Alanda Kentsel İç Mekanları Placemaking Süreci Üzerinden Okumak: "Project

for Public Spaces” Derneğinin Çalışmalarının İncelenmesi”, 2. Ulusal İç Mimari Tasarım Sempozyumu 2018, 06-07 Aralık 2018, Trabzon

World Health Organization, World Report On Ageing and Health, Luxembourg, WHO Press, 2015, p.44.

URL-1: http://www.totmdergisi.org/articles/2008/volume15/issue3/2008_15_3_15.pdf [Erişim tarihi 3 Haziran 2018]

URL-2: http://www.who.int/features/factfiles/ageing/en/ [Erişim tarihi 5 Eylül 2018]

URL-3: http://im.businessht.com/2017/07/11/ver1499780755/1559934_1181177868afd88557875320dcb61040_orj.jpg [Erişim tarihi 5 Eylül 2018]

URL-4: http://www.who.int/ageing/publications/world-report-2015/en/ [Erişim tarihi 5 Eylül 2018]

URL-5: http://www.tuik.gov.tr/PreHaberBultenleri.do?id=30567 [Erişim tarihi 5 Eylül 2018]

URL-6: http://www.mevzuat.gov.tr/Metin.Aspx?MevzuatKod=7.5.4414\&Mevzuatlliski=0\&sourceXmlSearch [Erişim tarihi 5 Eylül 2018]

URL-7: https://www.aplaceformom.com/blog/history-caring-for-elders-08-06-2013/ [Erişim tarihi 5 Eylül 2018]

URL-8: http://www.mevzuat.gov.tr/Metin.Aspx?MevzuatKod=7.5.4414\&MevzuatIliski=0\&sourceXmlSearch [Erişim tarihi 5 Eylül 2018]

URL-9: https://wallex.wallonie.be/index.php?doc=21579 [Erişim tarihi 5 Eylül 2018]

URL-10: http://e-kutuphane.teb.org.tr/pdf/tebakademi/geriatri_2009/5.pdf [Erişim tarihi 5 Ekim 2018]

URL-11: https://eyh.aile.gov.tr/yaslanma-2002-uluslararasi-eylem-plani [Erişim tarihi 5 Ekim 2018]

URL-12:http://www.kalkinma.gov.tr/Lists/zel\%20htisas\%20Komisyonu\%20Raporlar/Attachments/24 8/Ya\%C5\%9Flanma\%20\%C3\%96zel\%20\%C4\%B0htisas\%20Komisyonu\%20Raporu.pdf [Erişim tarihi 5 Ekim 2018]

URL-13:

https://sgb.saglik.gov.tr/Dkmanlar/T\%C3\%BCrkiye\%27de\%20Ya\%C5\%9Fl\%C4\%B1lar\%C4\%B1n\%20Durumu\%20ve\%20Ya\% C5\%9Flanma\%20Ulusal\%20Eylem\%20Plan\%C4\%B1.pdf [Erişim tarihi 3 Ekim 2018]

URL-14: http://www.tuik.gov.tr/PreIstatistikTablo.do?istab_id=1588 [Erişim tarihi 5 Ekim 2018]

URL-15: http://www.who.int/en/news-room/fact-sheets/detail/ageing-and-health [Erişim tarihi 5 Ekim 2018] 